\title{
EL EFECTO DE COSA JUZGADA DE LA SENTENCIA PENAL ABSOLUTORIA Y DEL SOBRESEIMIENTO DEFINITIVO EN EL PROCESO CHILENO DE RESPONSABILIDAD CIVIL
}

\section{THE EFFECT OF RESJUDICATA UPON A CRIMINAL ACQUITTAL PURSUANT TO CHILEAN LIABILITY PROCEDURAL RULES}

Ignacio Ried Undurraga"

\section{RESUMEN}

Este trabajo analiza el sentido y alcance de la norma del art. 179 del Código de Procedimiento Civil chileno, que establece el efecto de cosa juzgada en el proceso civil de las sentencias absolutorias penales y del sobreseimiento definitivo, en que por sobre el interés de la víctima, en obtener un resarcimiento patrimonial u otra prestación, prevalece el derecho fundamentalmente garantizado del non bis in idem del imputado absuelto y demandado civil. Esta prevalencia encuentra su fundamento en el análisis razonado de las coincidencias fácticas y dogmáticas entre los elementos del ilícito penal absuelto y del ilícito civil que se imputa en juicio.

Palabras clave: cosa juzgada, nos bis in idem, responsabilidad extracontractual.

\section{AbstRact}

This article analyzes the breadth and limits to the application of Article 179 of the Chilean Civil Code of Procedure, which describes the res judicata

\footnotetext{
* Abogado, licenciado en Derecho de la Pontificia Universidad Católica de Chile. Profesor de la Facultad de Derecho de la Universidad Diego Portales. Máster en Derecho Penal y Ciencias Penales de la Universidad de Barcelona y Universidad Pompeu Fabra, Barcelona. Dirección postal: Av. Andrés Bello 2711, piso 8, Las Condes, Santiago. Correo electrónico: iried@uc.cl. Artículo recibido el 21 de agosto de 2014 y aceptado para su publicación el 10 de noviembre de 2014.
} 
effect of a criminal acquittal and dismissal, in which prevails the civil defendant's constitutional right of double jeopardy over the victim's interest in obtaining just and fair compensation. The prevalence can be found in reasoned analysis of the factual and dogmatic similarities between the elements of the criminal offense and the elements of the civil breach.

Key words: res judicata, non bis in idem, torts.

\section{Planteamiento del problema:}

\section{LA ABSOLUCIÓN Y SOBRESEIMIENTO PENAL CON EFECTOS CIVILES LUEGO de la entrada en vigencia de la Reforma Procesal Penal}

En la ley procesal chilena está vigente una norma que permite invocar la cosa juzgada civil si se alega que previamente existió una sentencia absolutoria penal o un sobreseimiento definitivo fundado en la "inexistencia del delito o cuasidelito". Esta norma del Código de Procedimiento Civil dispone lo siguiente:

"Art. 179. Las sentencias que absuelvan de la acusación o que ordenen el sobreseimiento definitivo, sólo producirán cosa juzgada en materia civil cuando se funden en alguna de las circunstancias siguientes: $1^{\text {a }}$ La no existencia del delito o cuasidelito que ha sido materia del proceso. No se entenderán comprendidos en este número los casos en que la absolución o sobreseimiento provengan de la existencia de circunstancias que eximan de responsabilidad criminal”.

Esta norma, y sus equivalentes en el Derecho Comparado, han sido un quebradero de cabeza para la ciencia procesal, porque su aplicación no razonada permite llegar a soluciones injustas. Así, dota de efecto de cosa juzgada a una sentencia penal, sin el requisito de la triple identidad legal, irradiándose sus efectos más allá de los hechos mismos y de las personas del primer proceso absuelto o sobreseído. Esto trae como consecuencia que deba exonerarse de la responsabilidad civil al imputado respecto de hechos no absueltos en sede penal. Y, asimismo, permite sustentar la exoneración de un tercero civilmente responsable, ajeno también al proceso absuelto o sobreseído. En este trabajo intentaré dar una solución justa y razonada a ambos problemas.

La norma del art. 179.1 del Código de Procedimiento Civil cobra hoy una enorme importancia, dado el actual sistema procesal penal vigente en Chile a partir del año 2005. La reforma procesal penal ha limitado la actuación del demandante civil dentro de este proceso a su mínima expresión. Hoy, 
el demandante civil solo podrá hacer valer su pretensión resarcitoria en la medida que, además, sea la víctima directa del delito, y solo en contra de quien revista la calidad de imputado. Y tampoco en cualquier procedimiento: solo en la medida que el proceso llegue a un juicio oral, que, estadísticamente, sucede en una ínfima proporción de los casos penales. Todas las otras pretensiones resarcitorias que quieran interponer terceros afectados contra terceros responsables, o la misma víctima contra el imputado, o contra un tercero, pero en procedimientos que no sean un juicio oral, han sido desterradas del proceso penal, y son competencia del juez civil $^{1}$. Esta intromisión de lo penal en lo civil, cuya manifestación no es solo esta norma, no tiene un correlato equivalente en la débil intromisión que tiene el juez civil en el proceso penal ${ }^{2}$. Sucede así que la víctima/ demandante civil, desterrada del proceso penal chileno, donde apenas puede reclamar una indemnización de perjuicios en contadísimos casos, llega a tocar la puerta de un proceso civil donde -si existió absolución o sobreseimiento por no existir delito- se le volverán a cerrar las puertas, si se aplica en forma injusta y no razonada esta norma.

Esta situación es la opuesta a la que existía en el antiguo sistema procesal penal chileno, vigente en Chile durante más de cien años. En esa vigencia del antiguo proceso, lo que la norma fomentaba -por razones de economía procesal, justicia y protección a la víctima- era que las pretensiones civiles se ventilaran en el mismo proceso penal.

En este trabajo pretendo resolver dos problemas que, por su poco desarrollo dogmático, generan soluciones injustas en los casos llevados a la justicia. El primero, es el referido al derecho del imputado a no ser enjuiciado civilmente, con posterioridad a que resultó absuelto o sobreseído en sede penal. Y el segundo, se refiere al efecto erga omnes de las sentencias absolutorias penales que aprovechan al tercero civilmente responsable.

Respecto del primer problema, puede en efecto resultar injusto que el imputado, quien ya afrontó un proceso penal en el que fue absuelto o sobreseído, deba ser arrastrado nuevamente, ahora a un estrado civil, a demostrar su inocencia. En este trabajo se dirá que esa situación, cuando existe una correspondencia importante entre el juicio penal y civil, vulnera la garantía del non bis in idem. La opción tomada por el nuevo Código Procesal Penal al relegar el papel del demandante civil, parece dar un valor preponderante a los derechos del imputado por sobre los de la víctima, que ceden a favor de los primeros. Esta norma ha tenido múltiples interpretaciones, pero no ha sido mirada desde la óptica de este conflicto evidente entre los

${ }^{1}$ Este tema es analizado en detalle por Horvitz (2004), pp. 604, 605, 612; CuRY (2009), p. 807; Corral (2004), p. 52; Pizarro (2005) y Marín (2005).

${ }^{2}$ Cfr. Cury (2009), pp. 99-100 sobre las razones de esta autonomía, y la anterior dependencia del Derecho Penal al Derecho Civil. 
intereses de la víctima y los derechos del imputado. Respecto del segundo problema, esto es, el efecto erga omnes de las sentencias absolutorias o de sobreseimiento, se expondrá la razón que sustenta este efecto de cosa juzgada -o "efecto reflejo" de la sentencia- aun en beneficio del tercero civilmente responsable, que no es otra que la preferencia expresa que ha hecho nuestro legislador de la estabilidad de los pronunciamientos, por sobre los intereses de la víctima.

Para resolver ambas cuestiones, se hace necesario un estudio acabado de esta norma a la luz de estos principios e intereses que chocan (derechos del imputado vs. interés de la víctima; estabilidad de los pronunciamientos vs. interés de la víctima), los que debidamente ponderados, como diría Robert Alexy ${ }^{3}$, permitirán dar una interpretación razonable de la misma, haciendo prevalecer los primeros por sobre los segundos, cuando existe coincidencia entre la absolución y el nuevo proceso civil. Como sucede al tratar cualquier tema relacionado a la cosa juzgada, es necesario un esfuerzo del intérprete por comparar lo que se falló en el caso anterior respecto de lo que se ventila en el caso actual, o sea, tratar de delimitar el objeto del proceso. Para ello creo necesario un examen novedoso, como el que se propone en este trabajo, que se aparte de las categorías dogmáticas que suelen emplearse (cosa juzgada material, formal, triple identidad, cosa juzgada negativa, positiva, etc. ${ }^{4}$ ), que me parece están superadas e impiden resolver de forma adecuada estos problemas.

${ }^{3}$ Cfr. Alexy (2012), p. 349.

${ }^{4}$ Sin perjuicio de ello, valga aclarar que la norma del art. 179 parece consagrar una cosa juzgada de carácter material, o sea, valedera en un proceso ajeno a aquel en que la sentencia se pronunció, y con carácter de evidente inmutabilidad. Asimismo, tendrá un efecto de cosa juzgada negativa, en la medida que impide al juez del nuevo proceso fallar en contradicción con lo ya absuelto y sobreseído, como señala Romero (2011), p. 49, "cuando concurren los requisitos de la función negativa de la cosa juzgada, el órgano jurisdiccional debe evitar una nueva sentencia sobre el fondo, por estar resuelto jurisdiccionalmente el tema sobre el que se intenta volver a debatir. La función de la cosa juzgada tiene una naturaleza excluyente, siendo una proyección de la regla básica del non bis in idem". Hay que aclarar que Alejandro Romero reconoce este efecto negativo solo en aquellos casos en que existe una perfecta triple identidad. Para NiEva (2006), p. 146, por otra parte: "no tiene sentido, en definitiva, que el non bis in idem se aplique solamente cuando los objetos del juicios son idénticos, y en cambio se prescinda del mismo cuando dichos objetos simplemente se parecen”. Este autor, p. 144, estima -y lo comparto- que es imposible que "pudiera establecerse una diferencia real entre la eficacia positiva y la eficacia negativa de la cosa juzgada". Sin perjuicio de ello, y en lo referido al efecto de esta cosa juzgada frente a terceros -excepciones a los límites subjetivostambién puede verse el mismo fenómeno en su faz prejudicial o positiva, es decir, la absolución o sobreseimiento como presupuesto lógico que se integra a un supuesto de hecho de una norma, que es el mismo art. 179, que prohíbe un juzgamiento civil so pena de incurrir en contradicción con lo ya resuelto en sede penal; o como afirma Nieva (2006), p. 146, la obligación del juez "de poder juzgar solamente en parte, condicionado por la sentencia anterior". 


\section{UNA COSA JUZGADA SUI GENERIS \\ QUE NO EXIGE UNA ESTRICTA TRIPLE IDENTIDAD, PERO SÍ COINCIDENCIAS IMPORTANTES ENTRE AMBOS PROCESOS}

La naturaleza jurídica de la cosa juzgada es de los temas más discutidos en la dogmática procesal. Suele asimilársele a un efecto preclusivo, como cuando se habla de cosa juzgada formal (o sea, una especie de inmutabilidad temporal de las resoluciones, solo dentro del proceso en que se dictaron) o también como una presunción de verdad, lenguaje que empleó también el Código de Procedimiento Civil chileno, en su art. $427^{5}$, que trae al frente todos los problemas propios de las teorías sobre la verdad en el proceso. En lo que atañe a la cosa juzgada en general, nuestra legislación (art. 177) adoptó el sistema francés de la triple identidad, exigiendo entre el fallo anterior y la pretensión del nuevo proceso una coincidencia entre las partes, la cosa pedida y la causa de pedir ${ }^{6}$. Por su parte, el art. 179 se enmarca dentro de lo que la doctrina ha denominado el efecto de "prejudicialidad", esto es, que el fallo anterior es simplemente una "exigencia lógica" y un "requisito cronológico" de un juicio futuro o en curso, pero no terminado, expresando un "orden inmodificable de juicios", en las palabras del procesalista Enrico Allorio ${ }^{7}$. Se trata de una cosa juzgada que de manera abierta no exige de la triple identidad ${ }^{8}$, la que de todas formas

5 “Art. 427 (429). Sin perjuicio de las demás circunstancias que, en concepto del tribunal o por disposición de la ley, deban estimarse como base de una presunción, se reputarán verdaderos los hechos certificados en el proceso por un ministro de fe, a virtud de orden de tribunal competente, salvo prueba en contrario.

Igual presunción existirá a favor de los hechos declarados verdaderos en otro juicio entre las mismas partes".

${ }^{6}$ Cfr. Nieva (2006) y (2010). El estándar de la triple identidad no tiene mayor utilidad: si un nuevo juicio es idéntico a uno ya concluido mediante sentencia, no habrá duda en que sería absurdo repetirlo y, por tanto, operará la cosa juzgada. Pero los casos que se presentan en tribunales nunca son entre dos procesos idénticos, sino entre juicios que tienen algunos o varios elementos comunes. Como en todo, los problemas están en las "zonas grises". Entre nosotros, también fueron críticos de la triple identidad AlESSANDRI, SOMARRIVA Y VodANOVIC (1998), p. 139, quienes dijeron: "la receta parece ser muy sencilla para una realidad demasiado compleja". En el art. 216 del proyecto del nuevo Código Procesal Penalse ha eliminado esta exigencia, por sugerencia del profesor Cristián Maturana, solución que ha sido criticada por Romero (2014), p. 77, por ir en contra de nuestra "tradición jurídica".

${ }^{7}$ Allorio (2014), p. 71.

${ }^{8}$ La ubicación de este artículo, a continuación del art. 177 que sí exige la triple identidad legal, ha llevado a continuas confusiones a la doctrina y sobre todo a los jueces, quienes recurren a toda clase de razones para justificar por qué no es necesario cumplir con este requisito. El problema es más aparente que real, si se entienden los arts. 178 y 179 como normas especiales y preferentes al art. 177, aunque persiste el problema que todas estas normas emplean la misma e idéntica voz "cosa juzgada", definida en la primera de ellas. 
sería imposible de satisfacer. Nunca habrá coincidencia exacta entre las personas que intervienen en uno y otro proceso $^{9}$, lo que ha llevado a la doctrina y jurisprudencia a estimar que esta cosa juzgada tiene en verdad un efecto erga omnes, lo que es correcto.

Sin embargo, lo que propongo en este trabajo, es que el operador jurídico debe efectuar un análisis comparativo y razonado entre lo absuelto o sobreseído en sede penal y el nuevo proceso de responsabilidad civil, detectando si existen puntos de contacto importantes. El juez enfrentado al problema tiene la opción fácil de desechar la excepción de cosa juzgada si no se cumple estrictamente con la triple identidad del art. 177 o, bien, hacer un esfuerzo por detectar qué tan incompatible sería la sentencia del nuevo proceso con la ya dictada. En este último caso, la triple identidad asume su verdadero y original carácter, que era ser una simple guía para el juez, y no un límite estricto para obtener una salida fácil. Este análisis comparativo que propongo debe efectuarse respecto de las personas que han intervenido en ambos procesos, y respecto de los hechos de uno y otro.

Respecto de la identidad de personas (límites subjetivos de la cosa juzgada), habrá muchos casos en que se producirá coincidencia entre el querellante y el demandante civil, y también entre imputado y demandado civil, que serán la misma persona. Las coincidencia entre el querellante y 14 demandante civil, y entre imputado y demandado, por ejemplo, debiera ser un motivo poderoso para el juez al momento de aplicar el art. 179. Respecto de la cosa pedida y causa de pedir (límites objetivos de la cosa juzgada), como se verá a continuación, la doctrina ha eliminado este último requisito y ha transformado la "cosa pedida" en una simple coincidencia entre los hechos ventilados en uno y otro caso. Sin embargo, es posible reparar en interesantes zonas de convergencia entre lo pedido en uno y otro proceso. Lo que se pide en el juicio penal es la imposición de una sanción, fundada en la contravención a una norma prohibitiva tipificada en la ley, concurriendo los demás requisitos legales. En sede civil, por su parte, se exigirá una indemnización de perjuicios, fundada en la obligación genérica e indeterminada de indemnizar por la producción culpable o dolosa de todo daño en la propiedad o persona ajena. A propósito del análisis que hace Jesús-María Silva Sánchez, hay casos de responsabilidad civil ex delicto que consisten en "los daños que se manifiestan en el resultado típico del delito" y

"los daños trascendentes al resultado típico, pero en todo caso imputables a la conducta según las reglas de imputación objetiva y subjetiva que rigen en el ámbito de la responsabilidad extracontractual"10.

${ }^{9}$ Barros (2006), pp. 968-969.

${ }^{10}$ Cfr. Silva (2001). 
Ambas hipótesis dan cuenta de una responsabilidad que dimana de idénticos hechos. La causa de pedir en estos casos emana de normas diferentes, pero que sancionan el mismo hecho (una como ilícito penal y otro como ilícito civil). Asimismo, la cosa pedida-sanción penal y sanción civil- en muchos casos tendrá también un fin, un objeto que puede ser coincidente, como es la retribución o reproche (que emanan de la idea de la justicia correctiva) o, bien, la prevención especial o general, ideas todas que los civilistas chilenos han reconocido de forma unánime como fines de la responsabilidad civil por daños ${ }^{11}$. Nuestra jurisprudencia reciente ha denegado el efecto de cosa juzgada de la sentencia penal absolutoria o del sobreseimiento definitivo en aquellos juicios civiles en que la pretensión es una cosa distinta a una indemnización de perjuicios, entendiendo tácitamente que esta institución solo opera cuando exista una identidad entre el reproche penal (la pena)

${ }^{11}$ BARros (2006), pp. 33-55 diferencia en forma clara entre los fines que "operan como condiciones para atribuir la responsabilidad (justicia correctiva)" y los fines en sí mismos, que sería "disminuir las conductas indeseables". Estos últimos fines serían la perspectiva "instrumental y pragmática", propio de las "políticas públicas". El autor atiende a esta primera condición que permite atribuir la responsabilidad, y que opera como sustento material de ella, que sería la justicia correctiva, una de cuyas manifestaciones atendería exclusivamente al autor del daño, en cuyo caso la responsabilidad tendría un evidente fin retributivo del mal causado, como una vía de formularle un reproche personal. Aunque descarta que la indemnización civil tenga un fin de reproche o retributivo (en cuyo caso el monto de la indemnización dependería de la intensidad de la culpa del sujeto), advierte que "la práctica jurisprudencial chilena tiende a incorporar un elemento punitivo en la valoración del daño no patrimonial”. CORRAL (2004), p. 69 va más allá. Dice: "en nuestro sistema la finalidad sancionatoria no está del todo excluida, sino que concurre con la reparatoria. En efecto, la indemnización, aunque regulada en términos del daño causado es también comprendida psicológicamente tanto por la víctima como por el ofensor como una sanción al actuar imprudente o doloso de éste. Así también lo entienden los tribunales, siendo inevitable una apreciación de la gravedad de la culpa cuando se regulan los daños extrapatrimoniales, en los que la discreción judicial es amplísima". A propósito de las causas eximentes de responsabilidad civil, Rodríguez (2004), pp. 160-161: "es correcto extraer de las normas penales las causas de justificación en el campo civil. La responsabilidad es una sola. Ella toma diversas formas, dependiendo de los valores que aparezcan lesionados y los efectos de la contravención. Si el valor afectado [bien jurídico] es la integridad patrimonial, y el daño proviene de una conducta especialmente tipificada en la ley (delito), nos hallamos en el ámbito penal. En tal caso surge una acción penal para sancionar al culpable y una acción civil para la reparación del perjuicio causado. Si el valor afectado es la integridad patrimonial, y el daño proviene de una conducta genéricamente definida como dolosa o culposa, nos hallamos en el ámbito civil. Entonces sólo surge una acción civil para restaurar el perjuicio causado cuando éste deriva directa y necesariamente de la acción ilícita (dolosa o culpable). Como puede apreciarse, la diferencia entre ambos campos, siendo importante, no es sustancial. En ambos casos se responde del daño patrimonial que se causa en forma perfectamente similar. Si la responsabilidad penal exige la concurrencia del perjuicio patrimonial (como sucede en la estafa, el robo, el hurto, etc.), la similitud es aún más estrecha”. 
y el reproche civil (indemnización) y, por lo mismo, declarando que no hay incompatibilidad, por ejemplo, entre una sentencia que absolvió por los delitos de apropiación indebida y estafa y una posterior acción civil de cobro de honorarios ${ }^{12}$, o entre una absolución penal del delito de contrato simulado respecto de un juicio civil posterior referido a la nulidad de un contrato y restitución de un inmueble ${ }^{13}$.

Por tanto, la aplicación razonada de esta norma exige identificar los planos en que personas, cosa pedida y causa de pedir de la responsabilidad civil y penal se superponen. Esto lo intuyó el legislador al promulgar el Código de Procedimiento Civil, y lo siguen entendiendo de forma similar muchas legislaciones comparadas; sin ir más lejos, el proyecto de Código Procesal Civil chileno ${ }^{14}$ y el Código de Enjuiciamiento Penal español. La cosa juzgada del art. $179.1^{\circ}$ tiene como objetivo impedir que se superpongan sentencias contradictorias, lo que haría inútil el fallo anterior que es contradicho por un fallo posterior, dotando de coherencia y estabilidad al ordenamiento jurídico y sus resoluciones, cualidades que parecen ser inherentes a la función jurisdiccional misma ${ }^{15}$. Para Jordi Nieva la cosa juzgada es uno de los derechos que integran la "trilogía básica de Derechos Procesales", junto con los derechos de defensa y a un juez imparcial ${ }^{16}$. La no exigencia de la triple identidad en caso alguno impide este objetivo de coherencia recién apuntado, aunque exige naturalmente un esfuerzo dogmático importante para dilucidar cuándo existirá una contradicción o una incongruencia que la norma pretende evitar. Esta idea de "coherencia entre distintos sistemas" no es en todo caso pacífica. En realidad, puede resultar cuestionable para algunos que se exija una perfecta concordancia entre lo resuelto en sedes jurisdiccionales tan diferentes e inspiradas por principios tan distintos como son los tribunales laborales, de familia, civiles, administrativos, etc. ${ }^{17}$. Sin embargo, creo que claudicar a una mínima

${ }^{12}$ Sentencia de la Corte Suprema del caso Brañes con Foncea (2007).

${ }^{13}$ Sentencia de la Corte de Apelaciones de Santiago del caso Chico con Paya (2010).

${ }^{14}$ Proyecto que incluye el art. 219, cuyo inciso segundo dispone: "Las sentencias penales que absuelvan de la acusación o que ordenen el sobreseimiento definitivo respecto del imputado, sólo vincularán al juez civil cuando se funden en alguna de las circunstancias siguientes:

1. La no existencia del hecho que se le atribuyó;

2. No existir relación alguna entre el hecho que se persigue y el imputado, sin perjuicio de la responsabilidad civil que pueda afectarle por actos de terceros o por daños que resulten de accidentes, en conformidad a lo establecido en el título xxxv, libro IV, del Código Civil”.

${ }^{15}$ Cfr. Nieva (2006).

${ }^{16}$ Nieva (2014), p. 125

${ }^{17}$ Cfr. Eriksson (1997). Este autor cuestiona la "utopía” de pretender coherencia entre el sistema de Derecho Civil, movido por ideales individualistas, capitalistas y autorregu- 
coherencia es renunciar a una idea básica de justicia, que pretende asegurar a los ciudadanos que si en un primer juicio se falló que un determinado hecho ocurrió tiempo después un juez, de otra competencia, no resuelva que en realidad ese hecho jamás tuvo lugar. Como ha dicho Jordi Nieva:

"la división entre órdenes jurisdiccionales responde simplemente a razones de simple distribución del trabajo en función de la especialización. Pero en absoluto se ha pretendido nunca que los diferentes tribunales de cada jurisdicción se conviertan en compartimientos estancos, sino todo lo contrario" ${ }^{18}$.

La norma del art. 179 evidentemente no exige (ni puede exigir) una estricta triple identidad legal, y en ese sentido, se aparta por completo de la idea clásica de la cosa juzgada, acercándola a las teorías de los efectos "reflejos" de la sentencia o de la cosa juzgada, que se tratarán de manera breve a propósito del efecto erga omnes de esta norma. Pero la ausencia de la triple identidad legal no significa, en mi concepto, que la sentencia absolutoria o el sobreseimiento irradie sus efectos en forma total y sin excepciones, incluso, abarcando hechos o situaciones no exoneradas previamente. Esta norma en realidad pretende impedir sentencias contradictorias, y mantener la coherencia entre el sistema de justicia penal y civil, sea que se le atribuya un efecto preclusivo o, bien, si se adhiere a posturas un tanto anacrónicas como la de "presunción de verdad" 19.

latorios, con sistemas del Rechsstaat (estado de bienestar) como el Derecho del Trabajo. El reparo de Lars Eriksson es interesante, pero es muy probable que para el ciudadano de a pie resulte contraintuitiva la idea que un juez resuelva en forma diversa respecto de un mismo hecho, sólo por corresponder a competencias diferentes e inspirarse en principios también diversos.

${ }^{18}$ Nieva (2010), p. 58. En el mismo sentido, Nieva (2006), p. 241.

${ }^{19} \mathrm{El}$ art. 116.1 de la Ley de Enjuiciamiento Criminal española dispone: "la extinción de la acción penal no lleva consigo la de la civil, a no ser que la extinción proceda de haberse declarado por sentencia firme que no existió el hecho de que la civil hubiese podido nacer". Las diferencias con el art. 179.1 se advierten de forma inmediata. ARNAIZ (2004), p. 87, dice que entre los autores peninsulares la opinión más respetada es aquélla que considera que el art. 116.1 produce un "efecto preclusivo", que consistiría en que "el derecho a resarcimiento no se extingue por efecto de la declaración penal, sino por la exclusión de la facultad procesal para hacerlo valer judicialmente". También, que existiría "algo parecido a las mal llamadas presunciones iuris et iure, o a una formulación legal imperativa del supuesto de hecho que impide el nacimiento del derecho de resarcimiento cuando se den las circunstancias. La ley ha querido que cuando se den estas circunstancias no nazca el derecho a resarcimiento, porque parte de la formulación legal de su inexistencia. La ley en otras palabras, ha querido que no se dé el hecho constitutivo del supuesto de hecho del derecho a resarcimiento". 


\section{CulPa CIVIL, CULPA PENAL. DOLO CIVIL, DOLO PENAL}

Los malos entendidos respecto del requisito de la triple identidad legal tienen su origen, en buena medida, en el elemento subjetivo del ilícito; o sea, lo que sucedió en la mente del sujeto, de acuerdo con las categorías civiles y penales. Así, para Alex Carocca "no parece aceptable" que se opere la cosa juzgada civil a favor del imputado absuelto penalmente porque obró sin dolo o culpa, porque existen hipótesis en que sí puede haber responsabilidad civil en forma objetiva, sin culpa. En consecuencia, en nada obsta un pronunciamiento previo de la judicatura penal en el sentido de que no existió dolo o culpa. Esto es correcto. Pero tanto el criterio jurisprudencial como la crítica de Alex Carocca parecen generalizar a partir de casos particulares. Y, como hemos visto, la jurisprudencia no ha tenido problema en arribar a soluciones justas, aun en casos en que no existió culpa penal, pero sí civil. Para apreciar en propiedad la triple identidad, no ya como requisito, sino como guía para el juzgador, habrá que fijarse en las zonas coincidentes entre el elemento subjetivo del tipo penal absuelto o sobreseído, con la culpa y el dolo civil.

En la culpa van a existir necesarias coincidencias, ya que tanto el 18 Derecho Penal como el Civil se refieren indistintamente a conductas esperables, posiciones de autoridad, desidia, negligencia, descuido, etc. La gran diferencia está en la graduación civil de la culpa, que no existe en la ley penal, y en la existencia de ilícitos civiles objetivos, que no requieren culpa. Así, la culpa civil que exige una determinada norma civil o comercial no siempre coincidirá con el nivel de diligencia exigido por un determinado tipo penal que admite la modalidad imprudente. Pensemos en un delito imprudente que castigue la conducta desplegada por el sujeto incurriendo en cualquier clase de negligencia, mientras el cuasidelito civil por su parte solo castiga la imprudencia grave. $\mathrm{O}$, como indica Alex Carocca, aquellos casos en que la responsabilidad civil ni siquiera exige culpa (responsabilidad objetiva) en cuyo caso será irrelevante el elemento subjetivo que pudo existir -o no existir- en sede penal. Pero no es el único caso ${ }^{20}$.

${ }^{20}$ Dice Cury (2009), p. 810, que cuando en la sentencia penal "se excluyen tanto el dolo como la culpa, entendidos como elementos de la faz subjetiva del tipo, la responsabilidad civil desaparece, porque también ella se encuentra fundada en la existencia a lo menos de culpa, salvo algunos casos excepcionales de responsabilidad objetiva consagrados por la ley. Sin embargo, aun en estos casos puede ocurrir que para la obligación de reparar baste con una forma de culpa menos grave que la exigida por el tipo penal, como por ejemplo, si éste requiere imprudencia temeraria y para la afirmación de aquélla basta con la 'culpa lata'. En tales situaciones la responsabilidad civil subsistirá no obstante la exclusión 
Respecto del dolo, habrá que tener en cuenta las diferencias entre las categorías civiles y penales. El dolo penal, simplificadamente, es el conocimiento y voluntad de ejecutar la conducta típica. El dolo civil, en cambio, es la intención positiva de inferir un daño en otro o en sus propiedades, según la definición del Código de Andrés Bello. Dolo civil no es lo mismo que dolo penal. Podría darse el caso que el autor haya obrado con dolo penal (conociendo la conducta prohibida y queriendo realizarla de manera consciente o aceptándola al menos), pero no tener la "intención positiva de inferior daño o injuria en la propiedad o persona ajena" según lo define el Código Civil. Por ende, podría existir una determinada conducta en que concurra dolo penal (conocer/querer la conducta) y no haya dolo civil (querer sus resultados dañosos) ${ }^{21}$. Y viceversa: conductas

de la tipicidad. A su vez, la ausencia de dolo con subsistencia de culpa, que usualmente excluirá la punibilidad por inexistencia del tipo culposos correspondiente, no influye sobre la obligación de reparar, pues ésta descansa sobre uno u otro elemento subjetivo". En un fallo de 26 de noviembre de 1954, la Corte Suprema, resolviendo un recurso de queja, estimó que la inexistencia de dolo penal implica necesariamente la inexistencia del dolo civil, si se trata del mismo hecho, lo que pone en evidencia la confusión acerca de esta importante distinción, alimentada tal vez por tratadistas del Derecho Civil, como Fernando Alessandri Rodríguez que han insistido en que la culpa civil es indistinguible de la culpa penal. En este fallo la C. Suprema declaró: "cuando se sobresee, como en el caso actual, por no existir dolo o culpa en el hecho que se imputa a una determinada persona en el juicio criminal, no podrían concurrir estos mismos elementos del delito y del cuasidelito en la causa civil. El hecho es el mismo, idéntico. No puede dividirse; ver uno en el proceso penal y otro en el civil. Que es inconcuso entonces, que si no hay dolo o culpa imputable al señor Luco Mesa en las lesiones inferidas al querellante, no puede haberla tampoco en los daños originados al vehículo de este último, ya que el hecho es el mismo, único e indivisible".

21 "Para la atribución de dolo se requiere que el sujeto integre los conocimientos en un juicio sobre la concreta aptitud lesiva de su conducta, pero frente a la lesión que se supone prevista caben múltiples actitudes anímicas: indiferencia, preocupación, regocijo íntimo, resignación, etc. Casi todas estas actitudes son irrelevantes jurídicamente”, afirma VAN WEEZEL (2013), p. 516. En realidad, esas actitudes respecto del daño son irrelevantes para el Derecho Penal, no el Civil, que requiere que el sujeto haya deseado el resultado dañoso, según la definición del art. 44 del Código Civil. Nieva (2006), p. 236; respecto del efecto que tiene la sentencia penal absolutoria en el proceso civil español, haciendo suya la opinión de Emilio Gómez Orbaneja (Comentarios a la Ley de Enjuiciamiento Criminal, de 1951) concuerda con esta idea, señalando: "en el primer caso [se absolvió al imputado por la inexistencia del hecho] el Juez civil se ve vinculado por la declaración de inexistencia del hecho. En los otros cuatro [absolución penal fundada en la falta de tipicidad del hecho, concurrencia de una causal de exención de responsabilidad, de una causal de extinción de la responsabilidad, y de una excusa absolutoria], habiéndose pronunciado la sentencia sobre el hecho y la participación, también se vería vinculado en relación a estos dos extremos. Pero estaría completamente libre en cuanto a si el hecho causó el daño reclamable civilmente y en cuanto a la relación de causalidad. Y también sería libre con respecto a la declaración sobre la existencia de culpa civil, puesto que haber negado 
en que no haya dolo penal (siendo calificada como "casual" por el juez penal) y en que sí pudo existir dolo civil, en cuyo caso parecería que la excepción de cosa juzgada no debiera aplicarse. Asimismo, respecto del error de tipo, que puede significar que la conducta se estime como penalmente no dolosa y, por ello, no constitutiva de un ilícito penal, podría no ser apta para producir cosa juzgada en el juicio civil, desde que ese error abarcó solo el dolo penal (conocimiento o intención de ejecutar la conducta), pero no el dolo civil (querer positivamente la producción de un daño). Lo anterior, sin perjuicio de la responsabilidad penal que subsista por el correspondiente tipo imprudente, de existir.

El análisis no puede ser tan simplista al punto de decir que la norma del art. 179 no debe aplicarse porque la culpa penal del sujeto absuelto o sobreseído no se identifica con la falta de exigencia de culpa en ciertos casos de responsabilidad objetiva. En efecto en esos casos subsistirá la responsabilidad civil, y la norma no debiera aplicarse. Pero en muchísimos otros la norma deberá aplicarse, cuando la falta de negligencia que fundamentó la exoneración penal se identifica con la ausencia de la culpa exigida por el ilícito civil.

Ya analizados de modo muy breve los elementos subjetivos -dolo y culpa-corresponde hacer un análisis de las eximentes de responsabilidad, 20 y de la inimputabilidad penal y civil.

\section{EFECTO DE LAS CAUSALES EXIMENTES DE RESPONSABILIDAD PENAL Y DE LA INIMPUTABILIDAD PENAL EN EL PROCESO POR RESPONSABILIDAD CIVIL}

Puede suceder que la absolución o sobreseimiento penal estén apoyadas en la existencia de una eximente de responsabilidad o, bien, en la inimputabilidad del sujeto. Respecto las causales de justificación o eximentes de responsabilidad, valga una breve explicación acerca de la antijuridicidad penal y civil y, sobre todo, acerca de esta última, que está sustancialmente menos desarrollada en la doctrina nacional y extranjera.

El concepto de antijuridicidad -en general- está asociada a lo que es "contrario a derecho", ya sea en un sentido "formal", o sea, que contraviene una norma expresa, como "material", esto es, que no contraviene una norma expresa, pero sí los principios y valores del Derecho que informan todo el sistema. En la antijuridicidad subyace la idea del bien jurídico

que concurriera culpa penal no quiere decir que la civil, más leve, no pueda existir. Por lo demás, la existencia de causas de exención o de extinción de responsabilidad criminal, o de una excusa absolutoria, son irrelevantes para el Juez civil”. 
protegido, concepto que, si bien parece exclusivo de la dogmática penal, no es ajeno al Derecho Civil. Se trata de los valores, intereses y principios que consagra el ordenamiento jurídico y que resultan fundamentales para la convivencia pacífica y armónica en sociedad, y que permiten la mayor participación y desarrollo de los ciudadanos. Ejemplos clásicos son la propiedad, la vida, la integridad física, el respeto del ambiente. En materia penal, la antijuridicidad está muy ligada al concepto del tipo penal, o descripción típica. Es la ley penal la que expresa y taxativamente define qué conductas serán sancionadas por el sistema, todas conductas antijurídicas, claro está. Pero no todas las conductas antijurídicas están contenidas en un tipo penal que da origen a una norma penal. Existen muchas conductas -la inmensa mayoría- que, si bien contravienen el ordenamiento jurídico, no están tipificadas y, por tanto, no son penalmente antijurídicas, aunque sí pueden estar proscritas por el Derecho Civil, Administrativo, Tributario, Ambiental, etc. Consecuencia de esto es que el Derecho Penal es un sistema fragmentario, o de ilicitudes discontinuas, de excepcional aplicación, de ultima ratio, etc. La corriente de pensamiento que adhería al neokantismo asignaban al tipo penal (tatbestand en alemán, o "supuesto de hecho" de la norma) la ratio essendi del delito, o sea, su razón de ser, una condición necesaria, pero no suficiente), para estimar que existe un delito. El tipo era un "juicio provisional de desvalor o antijuridicidad", provisionalidad que se confirmaba si no concurría una eximente de responsabilidad, también llamadas causales de justificación ${ }^{22}$.

En materia civil, en cambio, parece no haber consenso acerca del contenido de la antijuridicidad civil, ni siquiera si esta es un elemento autónomo de este estatuto de responsabilidad ${ }^{23}$. En este punto adhiero a la postura que sí lo considera un elemento que integra la responsabilidad

${ }^{22}$ Mir (2012), p. 158.

${ }^{23}$ Así, Barros (2006), pp. 132-140, niega la existencia de la antijuridicidad como un elemento autónomo de la responsabilidad civil extracontractual, afirmando: "mientras en materia penal las causales de justificación excluyen la antijuridicidad del hecho típico, en sede civil actúan sobre la culpa, porque ésta se confunde con el juicio de ilicitud". Misma posición sostiene Alessandri (1983), y los tratadistas franceses Henri, León y Jean Mazeaud y André Tunc. Por su parte, Rodríguez (2004), pp. 129-162, la defiende latamente como un elemento autónomo sin el cual no se explica la existencia de causales de justificación que sean civiles, con el que estoy de acuerdo. En efecto es concebible un acto ejecutado con dolo civil (con la intención positiva de inferir daño a otro), pero que no sea antijurídico, por operar una causal eximente de responsabilidad civil, como sería la legítima defensa, en que el sujeto desea positivamente dañar a otro, pero para proteger un valor superior. La doctrina extranjera tampoco es pacífica en este aspecto. Así, Diez PicAzo y Gullón (1995), p. 827 niegan que el Código Civil español exija este requisito para configurar la responsabilidad civil por daños, lo mismo que Puig (1997), p. 81. A favor de este requisito, en cambio, esta la autora argentina GESUALDI (1997), p. 146. 
civil por daños, principalmente porque -como se verá- permitirá un análisis depurado y una debida contrastación con lo resuelto en sede penal, a efectos de aplicar la norma del art. 179.1 ${ }^{24}$.

En consecuencia, parece claro que el ámbito de posibles conductas antijurídicas es considerablemente más amplio para el Derecho Civil que para el Derecho Penal. Sin embargo, la doctrina civil muestra una notoria coincidencia con la ley penal a la hora de establecer cuáles son las excepcionales circunstancias que hacen que un hecho contrario a derecho no sea antijurídico. Hablamos, claro está, de las eximentes de responsabilidad civil, cuya nómina no está en ley civil alguna, a diferencia de lo que sucede en materia penal, en que están contenidas en el art. 10 del Código Penal, sin perjuicio de las llamadas "eximentes supralegales". Las eximentes civiles son de creación doctrinal y, por tanto, no hay consenso acerca de cuáles son y cuál es su contenido y alcance. En este trabajo, por tratarse de esa zona de contacto entre el Derecho Penal y Civil, solo trataremos de aquellas que recoge el mencionado art. 10 del Código Penal ${ }^{5}$.

Desde ya valga aclarar que el tenor literal del art. 179.1 excluye de manera expresa que la absolución o sobreseimiento penal produzca cosa juzgada en sede civil si la inexistencia del hecho en que se fundó, tenga como sustento que operó una eximente de responsabilidad criminal. Esto no obsta a que en sede civil pueda construirse y hacerse valer la misma circunstancia, pero como eximente de responsabilidad civil. En este caso no se hará valer como excepción de cosa juzgada, sino directamente como causal de justificación. De todas formas y, aunque la norma en forma

${ }^{24}$ RodRíguez (2004), p. 139 resume su postura al respecto con los siguientes postulados, en que independiza por completo la idea de antijuridicidad a la de dolo o culpa: "a) por regla general -expresión empleada explícitamente en la misma ley [art. 2329 del Código Civil es antijurídico todo daño que provenga de dolo o culpa de su autor, no en razón del dolo o la culpa, sino de su contradicción con el ordenamiento jurídico; b) Es igualmente antijurídico todo daño que sin provenir de un hecho doloso o culposo, ha sido provocado por una conducta prohibida o sancionada de cualquier modo en la ley (caso en el cual damos por establecido presuntivamente el elemento subjetivo del ilícito); y c) la regla general contemplada en el artículo 2329 inciso primero del Código Civil (alterum non laedere) no excluye, excepcionalmente, la responsabilidad sin dolo o sin culpa (responsabilidad objetiva) e incluye también excepcionalmente, la irresponsabilidad por daños causados por dolo o por culpa e los casos en que, por disposición expresa de la ley, desaparece la antijuridicidad, como sucede en las causales de justificación”.

${ }^{25}$ En general, la doctrina civil suele hacer coincidir las eximentes de responsabilidad civil con algunas de las que contempla la ley penal, aunque a veces incluyen en esta categoría otras que le son ajenas, como BARROS (2006), p. 137, que estima que el consentimiento del ofendido sería una eximente civil. Al respecto, valga decir que el consentimiento de la víctima -que no es una eximente penal- muchas veces será una causal de atipicidad de ciertos delitos (como el del art. 161-A, que requiere que la grabación subrepticia y su divulgación lo sean sin el consentimiento del ofendido, el hurto, ciertos delitos sexuales, etcétera). 
expresa lo niegue, parece configurarse una cierta obligación del juez civil de resolver en este punto en concordancia con lo ya manifestado por el juez penal, acogiendo la eximente, y en este sentido ese pronunciamiento anterior sería vinculante, en orden a mantener la coherencia entre los distintos sistemas ${ }^{26}$.

En el análisis particular de las eximentes de responsabilidad civil, Pablo Rodríguez afirma respecto de la legítima defensa que, a diferencia de lo que exige la norma penal (proporción en los medios),

"no es necesario atender al medio empleado para impedir o repeler la agresión ilegítima, sino al daño que se causa, el cual debe ser racionalmente proporcional al daño que se ha querido evitar".

Respecto del estado de necesidad, adhiriendo a la postura de algunos penalistas como Jesús María Silva Sánchez, Pablo Rodríguez sostiene que el agresor sí

“está obligado a reparar los daños causados, no en razón del delito o cuasidelito cometido, sino del enriquecimiento injusto que se produce entre el perjudicado y el autor del daño" ${ }^{27}$.

En cuanto al error de prohibición, o falso concepto acerca de lo penalmente permitido en el Derecho, pareciera ser que, aun de operar en sede penal y absolverse la conducta por no ser constitutiva de delito, su alcance respecto de la responsabilidad civil es improbable. El art. $8^{\circ} \mathrm{del}$ Código Civil dispone: "nadie podrá alegar ignorancia de la ley después que ésta haya entrado en vigencia", y el art. 706 a su turno: "el error en materia de derecho constituye una presunción de mala fe que no admite prueba en contrario". Por lo que un falso concepto del autor respecto de la prohibición penal de la conducta, podría servir para su exoneración penal, pero difícilmente en sede civil.

${ }^{26}$ Así lo entiende Rodríguez (2004), p. 152: “el derecho, por otra parte, debe interpretarse como unidad, lo que excluye vacíos, contradicciones e inconsistencias. Si una persona en el ámbito del derecho penal-siempre protector de valores de alta trascendencia social e individual-justifica una conducta, no puede ella, paralelamente, ser fuente de responsabilidad civil. No parece racional y lógico que se excuse a una persona por la destrucción y sacrificio de un valor superior (la vida por ejemplo) y se la responsabilice por el sacrificio de un valor de menor entidad (la propiedad)". En el mismo sentido, Cury (2009), p. 812.

${ }^{27}$ Rodríguez (2004), p. 157. Da el siguiente ejemplo: "si con ocasión de un incendio, el dueño de una propiedad valiosa se ve obligado a destruir una propiedad ajena de menor valor, a fin de evitar la propagación del siniestro (...). El beneficio que experimenta en su patrimonio tiene como antecedente el perjuicio que sufre el patrimonio ajeno, y éste no tiene otra justificación que evitar un mal mayor en el dominio propio". 
Respecto de la imputabilidad, los planos de coincidencia entre el Derecho Civil y Penal parecen más amplios. Así, referido a la imputación personal o "culpabilidad" -en cuanto todo delito es un hecho típico, antijurídico y culpable- Santiago $\mathrm{Mir}^{28}$ afirma que se trata en realidad de "la posibilidad de acceso normal" a la regl penal, siendo la "anormalidad motivacional" el fundamento de exclusión de la responsabilidad penal, que solo opera una vez verificado que nos encontramos ante una conducta humana, típicamente descrita en la ley, y respecto de la cual no opera una eximente de responsabilidad. En el plano de la exclusión de imputabilidad, me parece interesante la diferencia que hace Juan Pablo Mañalich, que distingue entre causas de inculpabilidad del sujeto debido a un déficit psicológico y las causas de exclusión de imputabilidad, como sería el estado de necesidad defensivo del art. $10 \mathrm{~N}^{\circ} 11$ del Código Penal. Dice que necesariamente la segunda presupone la existencia de la primera en el sujeto concreto, y que las causales de exculpación tendrían finalidades "político criminales de índole prevencionista" 29.

Dentro del estatuto de responsabilidad civil, por su parte, estas causales de exclusión de la imputabilidad que no se deben a un déficit psicológico, requerirán de un desarrollo doctrinal y jurisprudencial más profundo. De momento, Pablo Rodríguez reconoce el estado de necesidad defensivo -aunque permanece la obligación de indemnizar perjuicios-, pero no está claro qué sucede en otros casos, como el miedo insuperable o la fuerza irresistible (art. $10 \mathrm{~N}^{\circ} 9$ del Código Penal), u otras del Derecho Comparado (intoxicación plena por ingesta de bebidas alcohólicas, del art. $20.2^{\circ}$ del Código Penal español), aunque Enrique Barros cree que se exonera también de responsabilidad civil, al no existir siquiera una acción u omisión humana ${ }^{30}$. Estos conceptos de inimputabilidad han sido estudiados de manera profusa en la doctrina civil (que suele analizarlo al comienzo, y no al final, de la teoría del acto jurídico), y están recogidos en el Código Civil (art. 1447), y coinciden en ciertos aspectos con las causales de inimputabilidad del Código Penal (art. 10). Respecto de los actos

${ }^{28}$ Mir (2012), p. 547.

${ }^{29}$ Mañalich (2013), p. 726.

${ }^{30}$ Barros (2006), p. 71. En este punto, el estatuto de responsabilidad civil se aparta de manera sustancial del estatuto penal. Dice Enrique Barros, por ejemplo: "basta que el sujeto haya tenido control sobre su conducta para que ésta pueda serle atribuida. Esta voluntariedad elemental, que se expresa en el mero control de la acción, tiende a agotar el elemento subjetivo de la responsabilidad civil. No es siquiera necesario que el sujeto conozca los efectos de su conducta, pues basta que controle la decisión". Al igual que sucede en materia penal, este examen acerca de la voluntariedad es previo (aunque en sede penal es al final) al examen acerca del dolo civil, o sea, acerca de la "intención positiva" de ocasionar daño a otro. En consecuencia, el ilícito civil requiere de una conducta voluntaria y que además sea positivamente dolosa (o culpable). 
de los que el Código Civil denomina absolutamente incapaces -dementes, impúberes y sordos o sordomudos que no se pueden dar a entender de forma clara-comparto la opinión de Raúl Lecaros, coincidente con la de Santiago Mir recién transcrita, en el sentido de que:

"los incapaces absolutos tienen voluntad (de no tenerla, no serían personas), pero lo que sucede es que por razones internas, biológicas o psicológicas no podrán generalmente expresarla en forma válida" ${ }^{31}$.

Por último, plantea un problema el que se absuelva al menor de catorce años por ser inimputable penalmente (art. $10 \mathrm{~N}^{\circ} 2$ del Código Penal), en circunstancias que respecto de la responsabilidad civil, sólo se considera inimputable al menor de siete años (art. 2319 del Código Civil). En estos casos, la única responsabilidad civil que subsistirá será la de terceros civilmente responsables por el hecho ajeno, contemplando en forma expresa la ley civil algunos supuestos, como la responsabilidad civil de los padres por los actos de sus hijos, según dispone el art. 2321 del Código Civil ${ }^{32}$.

\section{Pauta COMParativa de LAS CATEgorías dogmáticas}

DE LA RESPONSABILIDAD CIVIL Y PENAL

Como complemento y para mayor claridad de lo ya dicho, a continuación propongo una pauta esquemática que permitirá determinar si es razonable aplicar el art. 179.1 a un determinado caso ya absuelto o sobreseído por la justicia penal. Como acota Jordi Nieva:

"para conocer cuál es el objeto del juicio, debemos fijarnos en el objeto de cada juicio. Y ello obliga a abandonar cualquier teorización, no quedando otro remedio que hacer un recuento de todo aquello que ha sido juzgado" 33 .

${ }^{31}$ LeCARos (1997), p. 62.

${ }^{32}$ Un ejemplo interesante lo encontramos en la sentencia Saavedra con Compañía de Tracción y Alumbrado Eléctricos de Santiago (1911), que hizo responsable civil al padre de un menor de catorce años por el atropello del que fue autor, con resultado de muerte (conduciendo un carretón) de un tercero, desmarcándose expresamente del sobreseimiento penal que benefició al imputado por ser menor de edad e inimputable.

${ }^{33}$ Nieva (2010), p. 14. Acerca del objeto del juicio en la teoría de la acción, Nieva (2014), p. 52. 
Sin perjuicio de la opinión del profesor, creo que sí es posible efectuar una teorización, a partir de las coincidencias existentes entre categorías dogmáticas de la teoría del delito y del ilícito civil.

\section{Cuadro:}

Coincidencias entre los elementos de la responsabilidad penal y civil ${ }^{34}$

\begin{tabular}{|c|c|c|c|c|}
\hline $\begin{array}{c}\text { Tipo objetivo } \\
\text { (conducta externa) }\end{array}$ & $\begin{array}{c}\text { Tipo subjetivo } \\
\text { (dolo/culpa) }\end{array}$ & $\begin{array}{c}\text { Antijuridicidad } \\
\text { (falta de eximente } \\
\text { de responsabilidad) }\end{array}$ & $\begin{array}{c}\text { Imputabilidad } \\
\text { personal } \\
\text { ("culpabilidad") }\end{array}$ & $\begin{array}{c}\text { Resultado exigido } \\
\text { por el tipo }\end{array}$ \\
\hline Capacidad & $\begin{array}{c}\text { Hecho ilícito } \\
\text { (doloso/culpable) }\end{array}$ & Daño & $\begin{array}{c}\text { Antijuridicidad } \\
\text { (falta de eximente } \\
\text { de responsabilidad) }\end{array}$ \\
\hline
\end{tabular}

De acuerdo con este esquema, la cosa juzgada del art. 179.1 será aplicable en un caso civil, siempre que existan las coincidencias que se detallan a continuación.

- En primer lugar, debe revisarse la coincidencia en cuanto a los fines de la sanción penal perseguida en su momento por el Ministerio Público, y el fin u objeto que persigue el demandante civil en el proceso posterior. Si en este último se pretende una declaración que se aparta del resarcimiento patrimonial cuya fuente es la responsabilidad que emana del mismo hecho ya absuelto en sede penal, podría no ser razonable aplicar la norma de exoneración civil. Los tribunales superiores son reacios a acoger la cosa juzgada cuando en sede civil se solicita la nulidad de un contrato o la reivindicación de una cosa, y no una indemnización.

- En segundo lugar, debe existir una coincidencia en cuanto el hecho ventilado en uno y otro proceso. Deberá contrastarse el contenido de la pretensión acusatoria y, sobre todo, la descripción típica -faz objetiva- del ilícito penal con los hechos que sustentan la demanda civil. El sobreseimiento o absolución lo debe ser también respecto del hecho que se imputó en sede penal. El hecho que sirve de base en uno y otro proceso debe ser coincidente en cuanto al momen-

${ }^{34}$ La antijuridicidad penal tendrá su correlato en el hecho ilícito civil, si se adhiere a las teorías que niegan la existencia de la antijuridicidad como elemento autónomo de la responsabilidad por daños. Cfr. BARRos (2006). 
to en el tiempo, lugar, personas que intervinieron y conductas desplegadas, y la forma en que actuaron los involucrados. Debe existir coincidencia entre la víctima penal y el demandante civil, no así necesariamente entre el imputado y el demandado, quien podría ser un tercero civilmente responsable, como se dirá más adelante. Es decir, coincidencia entre el tipo objetivo y los hechos que sustentan la pretensión civil. Si el hecho objetivamente típico no existió para el tribunal penal, podría de igual forma subsistir un hecho jurídicamente -o antijurídicamente, mejor dicho- relevante para el Derecho Civil, en la medida que haya ocasionado un daño. Por el contrario, si la descripción típica exige la ocurrencia de un perjuicio, de haberse absuelto por no ser la conducta objetivamente típica, es claro que no podrá subsistir como ilícito civil tampoco.

- El tipo subjetivo del delito sobreseído o absuelto debe ser coincidente con la culpa o dolo civil que se imputa en el nuevo juicio. Aunque se trate de conceptos diversos, en muchos ilícitos puede haber amplias zonas de contacto entre dolo con que actuó el sujeto para delinquir y el dolo que exige el Derecho Civil (piénsese en el delito de daños, por ejemplo). En este sentido, la coincidencia en el plano de los delitos imprudentes parece ser mucho mayor en cuanto a la culpa que se exige en uno y otro estatuto, pero siempre evaluando las diferencias que pueden existir en uno u otro caso. En un delito que solo se castiga por "imprudencia temeraria", hay una zona no coincidente si el delito civil solo exige obrar con culpa grave o lata. Asimismo, no será coincidente una imputación dolosa en sede penal, ya absuelta, con una imputación por negligencia en sede civil, sea respecto del mismo imputado, o de un tercero civilmente responsable.

- El bien jurídico protegido, el interés resguardado por el tipo penal, y por el ilícito civil que se denuncia, deben ser también coincidentes, es decir, la conducta debiera ser antijurídica en el mismo sentido, para el Derecho Civil como Penal.

- Como hemos visto, en general puede existir una amplia coincidencia entre la causal de justificación que eximió de responsabilidad al imputado en sede penal, con aquella que podría proceder también en sede civil, de acuerdo con la doctrina moderna. Sin embargo, por aplicación del art. 179.1 esta eximente debiera alegarse y acreditarse en sede civil, y no podría hacerse valer por la vía de la cosa juzgada.

- En cuanto a la inimputabilidad del acusado penal, en la mayoría de los casos será coincidente con la falta de capacidad civil para responder en esta sede, sea que se deba a un déficit psicológico como a conductas que no han sido plenamente voluntarias. 
- Por último, respecto de aquellos tipos penales que requieran de un resultado separado de la conducta ilícita o, bien, una condición objetiva de punibilidad (como podría ser el elemento "perjuicio"), existirá necesariamente su correlato civil en la producción del daño, conditio sine qua non para que exista responsabilidad. Esto no significa que solo aquellos tipos penales que exijan la producción de un daño podrán engendrar, además, responsabilidad civil.

\section{VI. ¿'INEXISTENCIA DEL HECHO \\ O INEXISTENCIA DEL DELITO O CUASIDELITO?}

La falta de una pauta comparativa como la recién expuesta, que permita razonar soluciones para los problemas que plantea el art. $179.1^{\circ}$, ha llevado a la doctrina adoptar posturas extremas que, hay que decirlo, vienen precedidas de las mejores intenciones, como es evitar una injusticia. Así, a pesar de que la norma habla literalmente de la "inexistencia del delito o cuasidelito" como requisito para que la sentencia absolutoria penal tenga eficacia en el proceso civil, la doctrina nacional ha insistido que lo que el legislador quiso decir es "inexistencia del hecho".

Respecto del alcance del tenor literal del art. 179.1, Juan Carlos Marín ha interpretado:

"si el tribunal de juicio oral en lo penal declara en su sentencia absolutoria que la acción u omisión por la cual se acusó a un individuo no era constitutivo de delito o de cuasidelito, esta declaración de absolución produce pleno efecto en el respectivo proceso civil”35.

Enrique Barros hace una exégesis diferente, a partir de la interpretación que hace de ciertos pronunciamientos jurisprudenciales. Dice:

"la inexistencia del delito puede deberse a una razón de índole material (no se ha cometido el hecho) o a una razón jurídica (los hechos no son constitutivos de delito desde el punto de vista penal). La jurisprudencia ha interpretado correctamente esta norma, señalando que sólo se refiere a la inexistencia del hecho,

${ }^{35}$ MARÍn (2005), p. 42. Sin embargo, advierte el autor: "esta solución no deja de causar cierta perplejidad. Ya hemos visto que el ilícito civil no emana del ilícito penal, por lo que la declaración de que no hubo delito (acción típica, antijurídica y culpable) no debiera afectar la competencia del juez civil para establecer la existencia de un ilícito civil (acción u omisión culpable que causa un daño)". 
precisamente en consideración a que los elementos del ilícito civil son menos estrictos que los del delito penal. La no existencia del delito aludida por la norma sólo se refiere a la declaración positiva por los sentenciadores penales de que no existen los hechos que resultan relevantes tanto en materia civil como en materia penal, y no a la calificación jurídica de esos hechos" ${ }^{36}$.

Esta postura de Enrique Barros puede haberla tomado de las opiniones que suelen ser más incluyentes en el foro procesal civil chileno, como son el Manual de Derecho Procesal Civil de Mario Casarino ${ }^{37}$ y del Repertorio de Legislación y Jurisprudencia.

Creo que la interpretación que hacen Enrique Barros y Mario Casarino no es correcta. En primer lugar, como se verá, porque la jurisprudencia no ha establecido lo que estos autores dicen que fijó como criterio. En segundo lugar, porque la ciencia del Derecho Penal se construye sobre la base de la existencia, precisamente, de un hecho del hombre, de una conducta humana. Los casos en que no existe delito porque no hay siquiera acción humana son tan escasos e infrecuentes que apenas merecen la atención del Derecho Penal ${ }^{38}$. Entonces, ¿̇se justificaba una norma procesal expresa

${ }^{36}$ Barros (2006), pp. 965-966.

${ }^{37}$ Casarino (2012), pp. 142-143, distingue las siguientes situaciones: “a) La sentencia penal o el sobreseimiento resuelven que no hay delito o cuasidelito penal porque los hechos en que se fundan no existen. En este caso, no cabe la menor duda de que esas sentencias penales producen cosa juzgada en materia civil, pues no sería lógico que para una jurisdicción no exista un determinado hecho y para otra sí. (...) b) La sentencia penal o el sobreseimiento resuelven que no hay delito o cuasidelito penal porque, si bien los hechos existen y están probados, ellos no están sancionados por la ley penal. En este caso, esas sentencias penales no producen cosa juzgada en materia civil, puesto que un hecho que no reviste caracteres de delito o de cuasidelito penal no excluye la posibilidad de que constituya, en cambio, un delito o cuasidelito civil, esto es, un hecho cometido con dolo y culpa y que cause daño. (...) c) La sentencia penal o el sobreseimiento resuelven que no hay delito o cuasidelito penal porque, si bien los hechos existen y están castigados en la ley penal, la intervención del responsable en ellos ha sido casual. En este otro caso, esas sentencias penales absolutorias producen cosa juzgada en materia civil, pues no sería lógico que para una jurisdicción un determinado hecho hubiere sido ejecutado en forma casual, y para otra, con dolo o culpa...”.

${ }^{38}$ Dice Mir (2012), pp. 213-225: "la pregunta acerca de si concurre o no un comportamiento humano debe hacerse en relación con un determinado tipo penal. Sólo si importa decidir la concurrencia o ausencia de un determinado tipo penal tiene sentido preguntar si ha habido alguna conducta humana que lo haya podido realizar. Por ejemplo: sólo si existen motivos para creer que pueda haberse producido el tipo de homicidio es preciso indagar si la muerte fue debida a algún comportamiento humano". Los casos de ausencia de comportamiento humano que enumera son de escasa o nula ocurrencia práctica, como son los casos de fuerza física irresistible, los movimientos reflejos, los actos en corto circuito, las reacciones explosivas, las reacciones primitivas, los supuestos de paralización momentánea, la embriaguez letárgica, el hipnotismo, etcétera. 
que regulara un puñado de casos que la propia ciencia penal denomina "de laboratorio" por su infrecuente ocurrencia? Evidentemente que no. Por lo demás, el proceso penal mismo, las actuaciones de investigación y de persecución penal solo se movilizan cuando ocurre un hecho del hombre, una acción humana que parece reunir los caracteres copulativos de un delito. De toda la jurisprudencia que se analizó para este trabajo, incluyendo la que cita el propio Enrique Barros, en ninguna se advierte que la absolución o sobreseimiento penal hayan sido motivados por la "inexistencia del hecho".

En consecuencia, no es que los hechos no existan, como afirma Enrique Barros y Mario Casarino, sino que estos hechos -las conductas- que sí existieron, no son constitutivos de delito. Dice Enique Barros citando un fallo de 1934 emanado de la Corte Suprema que "tempranamente" se resolvió:

"de la historia fidedigna del precepto legal que se supone infringido aparece que se dio a la circunstancia primera del art. 202 (actual art. 179) del Código de Procedimiento Civilla redacción que tiene por ser más comprensiva que la que se pretendió darle diciendo que en vez de delito o cuasidelito 'del hecho', dejándose establecido que la no existencia del hecho equivale a decir la no existencia del delito o cuasidelito".

Como queda claro de esta interpretación correcta de la Corte Suprema, lo que se dijo, entonces, es que el art. 179.1 al decir "la inexistencia del delito o cuasidelito" incluía, junto con varias otras hipótesis de posibles interpretaciones de esta norma, la expresión "inexistencia del hecho", y no -como cree Enrique Barros- que la primera queda reducida a la segunda. La propia Corte dice de manera que la interpretación que corresponde es "más comprensiva" y no "más restrictiva". Los otros fallos en que se apoya Enrique Barros van en el mismo sentido, estableciéndose que se produce la cosa juzgada cuando "el tribunal ha adquirido la convicción de no haberse perpetrado el hecho punible que dio origen a la causa" (año 1952, Corte Suprema ${ }^{39}$. La sentencia de la Corte Suprema de 21 de marzo de 1938 desmiente las conclusiones de Enrique Barros y Mario Casarino:

${ }^{39}$ Barros (2006), p. 966. Este último fallo del año 1952 contradice lo que el tratadista concluye: (1) sea que la Corte se convenció que el hecho mismo nunca ocurrió, eso no significa que la norma excluya per se otras hipótesis en que el delito o cuasidelito no ha existido, y (2) si la Corte se convenció de que el hecho punible (o sea el delito) no existió, como parecer dar a entender, eso significa que el art. 179.1 se entendió en el sentido de que la "inexistencia del delito o cuasidelito penal" son los que tienen efecto de cosa juzgada en sede civil. Dice este autor: "se ha fallado que si no se cumplen los requisitos para que haya estafa, pueden cumplirse las condiciones para que haya responsabilidad civil 
"la expresión 'de la no existencia del delito o cuasi delito' empleada en el Código de Procedimiento Civil para estimar procedente la cosa juzgada, que ha sido materia de este proceso, revela el mismo alcance que la del procedimiento penal, cuando autoriza el sobreseimiento definitivo por no aparecer que se haya verificado el hecho que dio motivo a formar la causa, o cuando al declarar que éste no es constitutivo de delito o cuasidelito, demuestra que se está en presencia de un suceso sin carácter ilícito, porque estas excepciones también eliminan toda responsabilidad civil, puesto que lo ilícito es lo permitido, según justicia y razón, legal o moralmente" ${ }^{40}$.

Alex Carocca aboga por la derogación del art. 179, rechazando el efecto que la absolución o sobreseimiento pueda tener el proceso posterior, fundado en "las diferencias existentes entre las responsabilidades penal y civil, que se manifiestan también en la estructura de los respectivos procedimientos",

"deficiencias propias de la prueba presentada por el o los acusadores, entre los cuales generalmente se encontrará el Ministerio Público, que actúa por motivaciones muy diferentes a las de la víctima y/o actor civil, por lo que no parece justo extender la cosa juzgada penal al juicio civil iniciada por estos últimos, ni aunque hayan participado en el juicio penal, pues en los delitos de acción penal pública su rol será siempre menos importante del que asumirá el organismo público de persecución penal"41.

por mala administración, y que la circunstancia de no existir responsabilidad penal por delito de incendio no implica liberar de una posible responsabilidad civil por culpa. Así también, del hecho que ciertas expresiones no cumplan los requisitos para que haya injuria, calumnia o difamación, no se excluye la responsabilidad civil por inmiscuirse en la vida privada". Todas estas hipótesis que plantea dan por sentado de que el hecho sí ocurrió, pero que no cumplía con los requisitos legales para ser calificado de ilícito penal. Por tanto, no es correcta, a mi juicio, la conclusión que extrae de estas decisiones jurisprudenciales, en orden a limitar el alcance del art. 179.1 a la "inexistencia del hecho".

${ }^{40}$ En esta sentencia se hace alusión también a la historia de la ley (del Código de Procedimiento Civil), que en su art. $179.1^{\circ}$ se apartó de los Códigos de la época, como una creación original. Asimismo, en este caso la Corte Suprema resolvió rechazar la cosa juzgada porque "el auto de sobreseimiento a que se ha hecho referencia no declaró la inexistencia del cuasi delito que se invoca en la demanda".

${ }^{41}$ Carocca (2006), p. 39. Estos argumentos y otros son expuestos y refutados por NiEva (2006), pp. 144-150, precisamente aludiendo al non bis in idem como garantía del imputado y demandado, y a la necesidad de estabilidad entre sentencias. Y señala de forma clara, p. 150, "cuando se dicta una sentencia absolutoria que tiene como antecedente una insuficiencia o una falta de pruebas 'no se produce la absolución en beneficio de la duda o ante la insuficiencia de pruebas, sino ante la certeza' de la inocencia del acusado al no haber quedado desvirtuada". 
Este autor también restringe el alcance de esta cosa juzgada, afirmando que el art. 179.1 no se debe aplicar en los siguientes casos:

(1) cuando los hechos existen y están probados, pero no están sancionados por la ley penal y

(2) cuando la intervención del responsable de ellos ha sido casual. Respecto de esta primera exclusión, Alex Carocca se apoya en una serie de sentencias, al igual que Enrique Barros, y llega a la misma conclusión que este. Dice que esto "evita los dañinos efectos para víctimas que podría producir extender la cosa juzgada penal a un futuro juicio civil" 42 . La postura de Enrique Barros, Alex Carocca y Mario Casarino es entendible porque efectivamente la aplicación del art. 179 puede generar situaciones que la víctima civil considerará injustas. Sin embargo, desde ya hay que aclarar que la solución del legislador está lejos de ser un mero capricho o error, y tiene su fundamento en la importante coincidencia que puede darse entre las categorías dogmáticas de la responsabilidad civil y penal, como ya se expuso y, además, en el respeto a la garantía del non bis in idem del imputado, como se expone en el capítulo anterior a las conclusiones. No porque el demandante civil haya sido relegado del proceso penal, eso significa de manera automática que la jurisdicción civil puede darle la espalda a todo lo ya resuelto en esa sede, en orden a "equilibrar un poco las cosas" y "no dejar al actor civil con las manos vacías".

La respuesta correcta a este problema es comparar los elementos del ilícito civil absuelto o sobreseído con los elementos del ilícito civil que se enjuicia en un segundo proceso. Por ejemplo, si el delito o cuasidelito no existió en sede penal porque el imputado obró sin culpa, factor que es determinante en estimar que no existió cuasidelito civil, la norma del art. $179.1^{\circ}$ necesariamente deberá aplicarse.

\section{Prevalencia de los derechos del imputado absuelto O SOBRESEÍDO FRENTE A LOS INTERESES DE LA VÍCTIMA DEMANDANTE DE PERJUICIOS CIVILES COMO MANIFESTACIÓN DEL NON BIS IN IDEM}

El juez se enfrentará a un caso en que, hecho el análisis de los capítulos anteriores, podrá detectar todas o buena parte de las coincidencias expuestas, y se verá movido a aplicar la cosa juzgada al caso particular. En este apartado quiero exponer una particular razón material que sustenta la existencia de esta específica cosa juzgada -además de la evitación de fallos contradictorios- una vez comprobada la amplia coincidencia entre lo absuelto o sobreseído, y el nuevo proceso civil iniciado. Esta razón

${ }^{42}$ Carocca (2006), p. 40. 
material es la garantía del non bis in idem. Lo que se dirá aquí es válido, evidentemente, para aquellos casos que el demandado civil sea el mismo que fuera absuelto en sede penal, quien es el único titular de la garantía del non bis in idem. Así, respecto del tercero civilmente responsable, por ejemplo, valdrán otras razones materiales para sustentar esta cosa juzgada (no repetición de juicios, evitación de fallos contradictorios, coherencia del sistema, etc.), como las que se expondrán a propósito del efecto erga omnes. Ello, respecto del imputado, el sustento material de la cosa juzgada no se agota en la evitación de sentencias contradictorias, sino que toma forma en el respeto de su derecho de no ser enjuiciado dos veces por el mismo hecho.

Como anuncié al comienzo de este trabajo, la norma del art. 179.1 establece una clara preferencia -no absoluta- de esta garantía fundamental del imputado, la que prevalece por sobre el interés de la víctima de obtener una reparación pecuniaria por el ilícito civil cometido a propósito del delito penal. O, lo que es lo mismo, el interés patrimonial y legítimo de la víctima cede a favor de una garantía fundamental del imputado, como es el non bis in idem. El principio del non bis in idem está recogido de forma expresa en el inciso segundo del art. $1^{\circ}$ del Código Procesal Penal:

"la persona condenada, absuelta o sobreseída definitivamente por sentencia ejecutoriada, no podrá ser sometida a un nuevo procedimiento penal por el mismo hecho",

y su contenido también se desprende de la garantía fundamental del art. $19 \mathrm{~N}^{\circ} 3$ de la Constitución Política de la República, aunque no está expresamente consagrado ${ }^{43}$, y de los tratados internacionales ratificados por Chile ${ }^{44}$. Es un principio reconocido con amplitud en el Derecho comparado, propio del Derecho Penal liberal moderno.

En general, existe cierto consenso acerca de la aplicación de este principio cuando existe un concurso de normas penales respecto de un mismo hecho ("multiplicación excluida") ${ }^{45}$, y cuando se inicia un nuevo proceso

${ }^{43}$ Dice Nieva (2006), p. 201, a propósito del ordenamiento jurídico español: “aunque parezca increíble, ningún precepto de nuestro ordenamiento jurídico instituye directamente el principio non bis in idem, lo que ha obligado al Tribunal Constitucional a deducirlo del principio de legalidad penal del art. 25.1 CE".

${ }^{44}$ Cfr. NÁQuira (2008).

${ }^{45}$ Mir (2012), p. 662, se refiere al "concurso de leyes", o sea, "cuando uno o varios hechos son incluidos en varios preceptos penales de los que sólo uno puede aplicarse, puesto que su estimación conjunta supondría un bis in idem". Una sentencia de la Corte de Apelaciones de San Miguel de 24 de enero de 1996 estimó, por ejemplo, que el porte ilícito de un arma y las lesiones ocasionadas con ella no podían entrar en concurso material (y penarse ambas), a riesgo de vulnerar el principio del non bis in idem. 
penal respecto de un asunto también penal ya zanjado. Esto sucede al intentar encausar penalmente por segunda vez al mismo sujeto, respecto del mismo hecho, existiendo idéntica pretensión persecutora respecto del caso ya resuelto por sentencia judicial ejecutoriada. En este último caso, el non bis in idem toma la forma de cosa juzgada propiamente tal, cuyo efecto se restringe -a diferencia del alcance más amplio del non bis in idem- al efecto que produce una sentencia ejecutoriada en un nuevo proceso judicial.

Sin embargo, es bastante discutido que este principio sea aplicable cuando concurren normas penales, o procesos penales ya terminados, respecto de nuevos procesos civiles o administrativos. En esta investigación se propone que este principio sí se aplica, bajo ciertos supuestos, a estos últimos casos. La historia de la ley resulta esclarecedora en este punto. Como lo cita Juan Carlos Marín, en la sesión $N^{\circ} 11$ de la Comisión Mixta de senadores y diputados, que informó sobre el Proyecto de Código de Procedimiento Civil de 18 de diciembre de 1900 se afirmó por el comisionado Urrutia que el sentido del artículo 179 es "no obligarle [al imputado] en un segundo juicio, a comprobar nuevamente su irresponsabilidad ya debidamente ejecutoriada”. De esta última frase parece más que evidente que ya el legislador del 1900 tenía en mente un estricto respeto al principio del non bis in idem que favorece al imputado. El propio Juan Carlos Marín también lo entiende así:

"la razón aducida por nuestros legisladores encuentra su fundamento en que las tres excepciones tienen tanta fuerza respecto del delito y de la participación del acusado, que no resulta razonable hacerle nuevamente rendir prueba en el proceso civil respectivo" ${ }^{46}$.

Parece claro que el non bis in idem beneficia también al imputado que ha sido absuelto en sede penal, respecto de los procesos judiciales que se

${ }^{46}$ Marín (2005), p. 41. El autor da cuenta de la objeción del comisionado Riesco para cambiar la redacción del artículo 179.1 en el sentido de que la excepción solo se refiriera a la "inexistencia del hecho" y no del "delito o cuasidelito", lo que fue contestado por Urrutia en los siguientes términos: "el primero dice que procede la cosa juzgada cuando la sentencia se funda en la no existencia del delito o cuasidelito. ¿Habría sido preferible decir: la existencia del hecho? Es preferible la redacción adoptada en el Proyecto, porque puede haber muchos casos en que el hecho materia del juicio criminal exista sin carácter ilícito, y sin embargo a todas luces procede la excepción de cosa juzgada en causa civil. Se procesa a N por incendio que resulta evidentemente casual, o por homicidio, para citar estos ejemplos; todas las presunciones le acusan: el cuerpo del delito aparece de resalto; el cadáver tiene introducida el arma que produjo la lesión causa necesaria de la muerte, el reo es absuelto porque comprueba plenamente que en los respectivos considerandos, el incendio fue casual o hubo mero suicidio. El hecho que motivó el enjuiciamiento existe, y no obstante la cosa juzgada se impone desde luego sin nuevos trámites judiciales”. 
inicien en su contra, en que se pretenda hacer efectiva su responsabilidad civil respecto de los mismos hechos.

De esta manera, el non bis in idem, en lo que nos interesa en este trabajo sobre la cosa juzgada consiste,

(i) por un lado, en la garantía del imputado de no ser enjuiciado dos veces por lo mismo una vez declarado inocente en sede penal, aunque el juicio posterior tenga el carácter civily

(ii) por otro, en el interés general de que no existan fallos contradictorios.

Esta manifestación del non bis in idem es compatible con la posibilidad ser condenado en sede civil y penal por el mismo hecho. Así, no existirá infracción al non bis in idem si el imputado es declarado culpable en sede penal y además condenado civilmente en el mismo proceso o en otro proceso posterior Pero sí se verá violentada esta garantía si el sujeto absuelto es llevado a estrados de nuevo por el mismo hecho, pero ahora para enjuiciarlo por su responsabilidad civil. La doctrina procesal parece entenderlo precisamente de esta forma, esto es, como el derecho a no ser enjuiciado dos veces por lo mismo, una vez absuelto el imputado ${ }^{47}$. Por otra parte, en el foro nacional, resultan interesantes las voces reclamando la infracción al non bis in idem que se cometería en la superposición de ilícitos penales y administrativos respecto de los mismos hechos, que obedece a la misma lógica garantista defendida en este trabajo ${ }^{48}$.

${ }^{47}$ Así, Romero (2011), p. 49, señala: "la función negativa de la cosa juzgada tiene una naturaleza excluyente, siendo una proyección de la regla básica del non bis in idem". Nieva (2006), p. 149, a propósito del efecto de las sentencias penales en el proceso civil español, dice: "tampoco podría decirse que la cosa juzgada penal no deba tener la misma trascendencia que la civil por esta razón. En primer lugar, otro principio del proceso penal avala que así sea, justamente el non bis in idem, que desde luego impediría juzgar dos veces al declarado inocente, aún con falta de pruebas de dicha inocencia”. RomERo (2012), p. 266, señala respecto del art. 30 de la Ley de Defensa de la Libre Competencia (DL 211), que permite demandar los perjuicios en sede civil, luego de obtenida una sentencia condenatoria pronunciada por el TDLC que "no reconocer al tercero la posibilidad de utilizar la sentencia del TDLC llevaría a que tenga que repetir el juicio fundado en los mismos hechos que ya fueron juzgados. En nuestra opinión, tal situación no se justifica, atendido que infringiría el principio del non bis in idem (no dos veces lo mismo). En efecto, si defiende que se debe iniciar por el tercero una nueva causa, se terminaría imponiendo más de una mula fundada en los mismos hechos". Hay que aclarar que la garantía de "no ser juzgado" civilmente una vez que operó la absolución penal, tiende a no ser respetada en el proceso civil, en que el juez suele esperar la sentencia definitiva para resolver la excepción de cosa juzgada, sin perjuicio que el art. 301 del Código de Procedimiento Civil permite oponer la excepción en cualquier estado del proceso, incluso, al momento de oponerse las excepciones dilatorias antes de contestarse la demanda.

${ }^{48}$ Cfr. Alcalde (2011) y (2013), pp. 360-365. Señala: "la cosa juzgada no se constituye en fundamento del non bis in idem, sino que ambas instituciones aparecen inspiradas en 
Una objeción a esta postura es que, aplicando la misma lógica, la garantía del non bis in idem debiera extenderse también al penalmente condenado, a quien sería entonces ilícito someterlo a un nuevo juicio civil posterior o, incluso, condenarlo en esta sede por los mismos hechos ya reconocidos en el mismo juicio o en uno anterior. Pero esta objeción no es atendible, al menos por dos razones.

- En primer lugar, una razón de texto: no existe el riesgo de sentencias contradictorias, como lo asegura el alcance amplio en el proceso civil del efecto de cosa juzgada de la sentencia penal condenatoria (art. 178).

- En segundo lugar, porque siguiendo la pauta comparativa que se propone en este trabajo, un ilícito penal, cuyas categorías dogmáticas presentan una importante coincidencia con las categorías de un ilícito civil, tendrá además consecuencias civiles que deben ser declaradas. En cambio, siguiendo la misma pauta propuesta aquí, un ilícito penal absuelto no podrá generar consecuencias civiles que generen una obligación de resarcimiento para el imputado, siempre que exista una coincidencia con los elementos de exoneración del delito o cuasidelito civil que se invoca, refrendado, además, por una razón de texto, como es la norma del art. 179. Lo anterior, sin perjuicio de la responsabilidad civil imputable $a$ 36 terceros a que diere lugar el hecho.

En contraste con esta garantía del imputado, la víctima tiene un interés legítimo, y no una garantía constitucional propiamente tal, de ver reparadas las consecuencias patrimoniales perjudiciales ocasionadas por el hecho ilícito. Este interés se manifiesta a través de la acción civil de la que es titular la víctima, que no debe confundirse con el mal entendido "derecho" de la víctima a ejercer una acción penal en el proceso, o a perseverar en él, aun en contra de la voluntad del Ministerio Público, como lo ha establecido el Tribunal Constitucional tanto chileno como español ${ }^{49}$.

unos mismos principios jurídicos”. NÁQUIRA (2008), p. 19: “en la medida de que el ilícito administrativo o civil y el ilícito penal mantengan identidad de sujetos, hecho y fundamentos, parece más fácil justificar que se está frente a una violación al principio de non bis in idem, ya que se estaría sancionando dos veces el mismo hecho cometido". Sin embargo, este autor advierte la reticencia de la jurisprudencia nacional a adoptar esta postura, por la interpretación literal que se ha hecho del art. 20 del Código Penal, que expresamente establece que no se considerarán penas las "multas y demás correcciones que los superiores impongan a sus subordinados y administrados en uso de su jurisdicción disciplinal o atribuciones gubernativas", y del art. 120 de la ley $\mathrm{N}^{\circ} 18.834$ que aprueba el Estatuto Administrativo ("la sanción administrativa es independiente de la responsabilidad civil y penal"). CurY (2009), pp. 100-117 considera que entre el Derecho Penal y el Administrativo existe solo una relación "cuantitativa” (intensidad de las sanciones), pero no cualitativa.

${ }^{49}$ En Chile, sentencias de Tribunal Constitucional de los casos Meneses con Tribunal de Garantía de San Fernando (2008) y Visionone Chile S. A. con Cuarto Juzgado de Garantía 
Este interés legítimo del perjudicado por un ilícito emana, en un sentido material o sustantivo, de la norma del art. $19 \mathrm{~N}^{\circ} 24$ de la Constitución Política, que consagra el derecho de propiedad. En un aspecto procesal, la acción civil encuentra su reconocimiento en el art. $19 \mathrm{~N}^{\circ} 3$ (debido proceso), 76 (inexcusabilidad judicial), y también del deber que le asiste al Ministerio Público de proteger a las víctimas (art. 83), todos de la Constitución Política de la República. Asimismo, este interés está refrendado por múltiples disposiciones del Código Procesal Penal. Como hemos dicho, este interés legítimo de la víctima cede ante una garantía fundamental de mayor entidad como es el non bis in idem que beneficia al imputado. Como acota de manera correcta Andrés Bordalí:

"si han de considerarse derechos fundamentales en materia procesal penal, debe ponerse especial atención en la persona del imputado por delito y no de la víctima" 50 .

No debe perderse de vista que los derechos y garantías del imputado gozan de amplio reconocimiento y cobertura constitucional y legal, lo que no ocurre con los derechos de las víctimas del delito. La concepción liberal del Derecho Penal moderno debe ser necesariamente la de una construcción teórica en torno al imputado, en protección y respeto de sus garantías, con preeminencia evidente sobre las de los otros intervinientes del proceso ${ }^{51}$. Por lo demás, es esta y no otra la concepción de nuestro Código Procesal Penal, y así quedó también de manifiesto en la discusión en el Congreso. Es el imputado la parte débil de la relación procesal, es por lejos el interviniente cuya posición es más vulnerable y, por lo mismo,

de Santiago (2010), que reconocen a la víctima como titulares de derechos e intereses de persecución penal; en España, la sentencia del Tribunal Constitucional del caso Escudero con Sección Segunda de la Audiencia Provincial de Murcia (1994) y Montesinos con Sala Penal del Tribunal Militar Territorial Cuarto (1993), se le reconoce a la víctima la facultad o derecho de solicitar la actuación del ius puniendi del Estado a través de la acción popular.

${ }^{50}$ Cfr. Bordalí (2011). Complementa esta autor afirmando: "lo anterior se condice con el Derecho internacional de los derechos humanos, pues éste garantiza siempre las garantías de un proceso justo para quien es acusado por delito. Así puede verse en el artículo 6.1 de la Convención europea de los derechos del hombre; artículo 14.1 del Pacto internacional de derechos civiles y políticos; artículo 10 de la Declaración universal de los derechos del hombre; artículo 47, $2^{\mathrm{a}}$ línea, de la Carta de los derechos fundamentales de la Unión Europea, y artículo 8.1 de la Convención americana de derechos humanos. Estas cartas internacionales omiten todo derecho o exigencia sobre quien debe sostener la acusación. Cosa distinta, en todo caso, es que algunas de esas garantías del debido proceso deban garantizarse al ofendido por delito si es que participa del proceso penal. Ello puede derivarse del contradictorio como principio esencial al proceso".

${ }^{51}$ Cfr. Ferrajoli (2009) y Roxin (2008). 
es a él, y no a la víctima, en quien deben estar puestos los esfuerzos para evitar el respeto de sus garantías, sobre todo una tan importante como es la de evitar un doble juzgamiento. Como acota Luigi Ferrajoli:

"el presupuesto del garantismo es siempre una concepción pesimista del poder como malo, sea quien fuere quien lo posee, puesto que se halla expuesto, en todo caso, a falta de límites y garantías, a degenerar en despotismo" 52 .

La pretensión de cierta parte de la doctrina de "subsidiar" a la víctima a través de una interpretación restrictiva y contra legem del art. 179.1, no es atendible como forma de compensar el limitado campo de acción que en la actualidad tiene en el proceso penal. Que haya sido "expulsada" o "relegada" del juicio penal, no puede ser el fundamento para que la víctima se desentienda limpiamente de lo ya resuelto en un proceso anterior en contra del imputado por los mismos hechos. En este sentido, las restricciones propuestas por la doctrina citada, en orden a que el 179.1 solo operaría cuando en el juicio civil se absolvió por la "inexistencia del hecho" no es sino una velada forma de analogía in malam partem.

$\mathrm{El}$ art. 179.1, por su ubicación en un cuerpo legislativo ajeno al Derecho Penal, ha sido interpretado de espaldas a las garantías procesales que inspiran el proceso criminal, y se le ha dado un alcance restringido sobre la base de premisas erróneas, y sin considerar para nada la preeminencia que debe existir de los derechos del imputado. Lo que propongo es un respeto del interés patrimonial de la víctima, en la medida en que no exista una coincidencia total (o al menos muy significativa) con los aspectos principales de lo ya resuelto por el juez penal ${ }^{53}$. El interés patrimonial de la víctima, cuyo ejercicio es facultativo y, por tanto, plena manifestación de su autonomía, debe, entonces, ceder frente a los derechos fundamentales del imputado a no ser juzgado dos veces por el mismo hecho. Para Luis Prieto en estos casos ni siquiera hay conflicto que pueda ponderar-

${ }^{52}$ Ferrajoli (2009), p. 885.

${ }^{53}$ Prieto (2013), p. 93 cita a Luigi Ferrajoli en lo referido a que "los derechos de autonomía no colisionan con las libertades fundamentales, sino que vienen sometidos a su imperio; nuestra capacidad negocial privada y nuestra economía política indirectamente expresada en la ley tienen su frontera en el conjunto de los derechos fundamentales, y este sería el meollo del constitucionalismo rígido: los derechos triunfan siempre por sobre el mercado y la política. Aquí existe una subordinación estructural de los derechos secundarios (de autonomía) a los derechos primarios (inmunidades, libertades y derechos sociales)". Aunque hay que acotar que esta idea no es compartida por el propio Luis Prieto, en lo referente a la pugna entre libertades fundamentales y derechos de autonomía cuyo titular es el mismo sujeto. 
se, porque siempre el derecho fundamental prevalece ${ }^{54}$. En este caso, la pretensión civil de la víctima o del demandante tiene una doble faz: por un lado, interés patrimonial, y como tal, disponible y renunciable y, por otro, afectación al derecho al non bis in idem del imputado.

Siguiendo la línea de ideas de Ronald Dworkin, no se trata de una confrontación entre una norma que consagra el interés de la víctima, y un principio, como el non bis in idem, sino que lo que sucede es que se "sopesan los principios y las directrices a cuyo servicio está la norma”, por lo que "induce a error decir que el tribunal compara el peso de la norma misma con el de uno u otro conjunto de principios" $" 55$. Usando la nomenclatura de este autor, parece existir una preferencia del derecho concreto del non bis in idem, frente al principio abstracto de la víctima de acceder a la justicia y de obtener una reparación, siempre en el entendido del "universo dworkiniano" -al cual adherimos en este punto- de tomarse "en serio" los derechos individuales frente a las políticas gubernamentales de bienestar colectivo ${ }^{56}$.

Sin perjuicio de todo lo dicho respecto de la prevalencia de estos derechos del imputado, que defiendo en este trabajo, no debe perderse de vista que la regla del art. 179 es una regla de carácter excepcional, tal como lo ha entendido la doctrina de la expresión "sólo producirán cosa juzgada" que emplea el artículo. Así, en muchos casos prevalecerá el interés del actor civil por sobre la garantía del imputado -en todos los casos en que el sobreseimiento o absolución no provengan de la inexistencia del delito o cuasidelito, entre otros. Se puede decir que se cumple el que:

${ }^{54}$ PRIETO (2013), p. 87: "En resumen, presentar como conflictos dispuestos para la ponderación lo que son en realidad violaciones de derechos fundamentales equivale muchas veces a escamotear la fuerza normativa de los derechos".

${ }^{55}$ Dworkin (2012), p. 142.

${ }^{56}$ Dice Dworkin (2012), p. 162: “Cualquier teoría correcta se valdrá también de una distinción entre derechos concretos y abstractos. Se trata de una distinción de grado, pero analizaré ejemplos relativamente claros, tomados de los dos polos de la escala que contempla, y los trataré por consiguiente como una distinción genérica. Un derecho abstracto es una finalidad política general cuyo enunciado no indica de qué manera se ha de comparar el peso de esa finalidad general con el de otras finalidades políticas, en determinadas circunstancias, o a qué compromiso se ha de llegar entre ellas. Los grandes derechos de la retórica política son abstractos en este sentido. Los políticos hablan de derecho a la libertad de expresión, a la dignidad o a la igualdad, sin dar a entender que tales derechos sean absolutos, y sin aludir tampoco a su incidencia sobre determinadas situaciones sociales complejas. Los derechos concretos, por su parte, son finalidades políticas definidas con mayor precisión, de manera que expresan más claramente el peso que tienen contra otras finalidades políticas en determinadas ocasiones. (...) De esta manera, los derechos abstractos proporcionan argumentos a los derechos concretos, pero la reclamación de un derecho concreto es más decisiva que cualquier reclamación del derecho abstracto que le sirve de base". También AleXY (2014), p. 179, se explaya acerca de la colisión de derechos individuales con los bienes colectivos. 
"detrás de cada precepto legal siempre es posible encontrar un principio o norma constitucional que lo respalda, y también otro que lo contradice ${ }^{57}$.

La garantía del non bis in idem se inserta dentro del proceso civil a través de esta norma del art. 179, donde tiene, sin embargo, un alcance limitado, y estrechamente vinculado a la concordancia práctica (praktische konkordanz) entre lo absuelto o sobreseído en sede penal y la nueva pretensión civil ventilada. Solo en la medida en que esta coincidencia se dé en el caso concreto, la garantía fundamenta del imputado despliega todos sus efectos. En caso contrario, esto es, si no existió absolución o sobreseimiento fundado en las causales legales, y aun existiendo, la concordancia con lo debatido en sede civil no existe, debiera darse preferencia al interés de la víctima, y someter a juicio otra vez al imputado.

VIII. EL EFECTO ERGA OMNESRESPECTO DEL TERCERO CIVILMENTE RESPONSABLE.

UNA COSA JUZGADA SIN LÍMITES SUBJETIVOS QUE PRIVILEGIA LA ESTABILIDAD DE LOS PRONUNCIAMIENTOS

40 Lo dicho hasta este momento permite solucionar solo uno de los problemas planteados al comienzo, referido a los casos en que el imputado es llevado de nuevo a juicio (esta vez civil) por los hechos ya absueltos o sobreseídos en sede penal. Sin embargo, queda por resolver el problema del efecto erga omnes de la sentencia absolutoria y del sobreseimiento, del que se beneficia el tercero civilmente responsable. Se trata del interés pecuniario de la víctima, de resarcirse por el daño causado, que entra en conflicto con la pretensión del legislador de mantener la estabilidad y la coherencia de los pronunciamientos judiciales. Y como se dirá, el conflicto se resuelve a favor de la estabilidad.

La norma del art. $179.1^{\circ}$, cuando beneficia al tercero civilmente responsable, se enmarca dentro de un problema de mayor alcance que ha sido tratado de forma profusa por la ciencia procesal, referido al efecto "reflejo" de las sentencias (y de la cosa juzgada), y del efecto de la cosa juzgada frente a terceros. Puede decirse que estas discusiones son superfluas dada la claridad de nuestro Código de Procedimiento Civil, que, como hemos dicho, define de manera expresa que estamos frente a una hipótesis de cosa juzgada. Pero esto sería apresurado: lo cierto es que la aplicación de esta cosa juzgada puede generar consecuencias injustas, precisamente porque benefician a un tercero que nada tuvo que ver con el anterior proceso. La

${ }^{57}$ BAQuerizo (2009), p. 27. 
doctrina ha hecho esfuerzos no menores para aclarar la naturaleza de esta institución, que vale la pena enunciar, aunque será imposible profundizar en estas posturas, dada la naturaleza de este trabajo.

Por un lado, están los interesantes descubrimientos de Adolf Wach ${ }^{58}$, a partir de las ideas de Rudolf von Ihering, luego complementadas por Enrico Liebman ${ }^{59}$, que concebían el fallo del juez no solo como un "acto jurídico" que afectaba directamente a las partes del proceso sino, además, como un "hecho jurídico" que irradiaba sus efectos a terceros ajenos a él. Liebman hizo la distinción clara, por un lado, entre efectos que produce la sentencia, como sería el declarativo, constitutivo o de condena y, por otro, los efectos propios de la cosa juzgada, asimilando estos últimos a la inmutabilidad, denunciando la impropiedad que existiría -sin ir más lejos, en la propia ley chilena- de hablar de "cosa juzgada respecto de terceros". Lo que ocurriría, según este autor, es un efecto "reflejo" de los efectos propios de la sentencia -no de la cosa juzgada- en terceros ajenos a la causa, que nada tendrían que ver con su efecto de inmutabilidad ${ }^{60}$. La sentencia correspondería a un hecho jurídico o un presupuesto lógico que se integra en el supuesto de hecho de una norma diversa, de la que se derivan efectos colaterales no queridos ni deseados por los intervinientes, ni ciertamente por el juez (prejudicialidad). Esta tesis permitiría superar el problema que tantos dolores de cabeza ha dado a los procesalistas respecto de este efecto de cosa juzgada que se predica de terceros ajenos al proceso, y no solo de las partes ${ }^{61}$.

Más sencilla es la aproximación de Jordi Nieva, quien concibe la cosa juzgada como una institución que debe resguardar la coherencia en el siste-

${ }^{58} \mathrm{Cfr}$. WACH (1997). Este autor reparó en que las sentencias constitutivas -pensemos en la que declara en divorcio, por ejemplo- producen sus efectos no solo respecto de las partes sino que, eventualmente, interesan, se imponen o irradian a todas las personas. Si bien este planteamiento es correcto, comparto la teoría más moderna que las sentencias judiciales en general, y no solo las constitutivas de derechos, son actos o hechos jurídicos que irradian sus efectos mucho más allá de las partes litigantes, dada la interconectividad de sujetos y empresas, la facilidad de las comunicaciones, los procesos colectivos, etc. En el fondo, la sentencia es un fenómeno social, y no solo de las partes que participaron en el litigio.

${ }^{59}$ Cfr. Liebman (1946.)

${ }^{60}$ Op. cit., pp. $37-38$

${ }^{61}$ Estas ideas están latamente explicadas en el interesante trabajo de Rosende (2001), y recogidas por Romero (2012), a propósito del valor probatorio de las sentencias en un proceso posterior. Respecto de la prejudicialidad, TAPIA (2010), p. 257, al analizar la jurisprudencia española, señala: "es cierto que las sentencias firmes, si bien sólo producen los efectos de cosa juzgada (en su función negativa o en su función positiva) en un pleito posterior cuando se dan los requisitos legalmente establecidos, pueden producir el denominado por la doctrina y la jurisprudencia 'efecto reflejo' o 'efecto colateral', que no depende de la sentencia como acto jurídico, sino más bien de la sentencia como 'hecho jurídico"”. 
ma jurídico, evitar juicios contradictorios y, sobre todo, evitar la repetición de juicios. En este sentido, siempre habrá cosa juzgada cuando existan

(i) un enjuiciamiento anterior y

(ii) la necesidad de mantener la estabilidad del pronunciamiento; prescindiendo de la triple identidad, que por lo demás en el derecho español no existe desde la reforma a la Ley de Enjuiciamiento Civil que incorporó la cosa juzgada a ese cuerpo legal, derogándola del Código Civib² . Jordi Nieva, apoyándose en la postura sostenida antes por Enrico Allorio nota que la cosa juzgada contempla "demasiadas excepciones" a la regla de la identidad de partes (límites subjetivos), lo que provoca cuestionarse si es realmente un requisito propio de esta institución, señalando que dicha regla jamás fue tal en un comienzo, sino solo una "guía" formulada por el Derecho Romano ${ }^{63}$.

La teoría de los efectos "reflejos" de la sentencia como solución al problema de los "límites subjetivos", me parece una elaboración un tanto artificial y sin mayor consecuencia útil, aparte de la acotada por Cecilia Rosende ${ }^{64}$ en lo referido a subsanar la paradoja del efecto erga omnes de la cosa juzgada. De todas formas es claro que el art. 179 consagra una verdadera cosa juzgada: los terceros no pueden alterar la inmutabilidad de ese fallo, tal como no pueden hacerlo las partes, entendida teleológicamente este instituto procesal como un impedimento para que se generen sentencias contradictorias ${ }^{65}$.

Buena parte de la doctrina nacional se ha mantenido ajena a este debate cuando se trata de abarcar este problema. Para Enrique Barros, esta cosa juzgada produce efectos erga omnes, porque

${ }^{62}$ El art. 222.1 de la Ley de Enjuiciamiento Civil española mantuvo solo la identidad de objeto: "la cosa juzgada de las sentencias firmes sean estimatorias o desestimatorias, excluirá, conforme a la ley, un ulterior proceso cuyo objeto sea idéntico al del proceso en que aquélla se dedujo".

${ }^{63}$ Nieva (2006), pp. 198-228; Allorio (2014), p. 75 dice muy gráficamente: "las hipótesis que suelen calificarse como casos 'particulares' de extensión de cosa juzgada, y agruparse como excepciones al 'principio' de los límites subjetivos de la cosa juzgada, realmente en su gran mayoría no son excepciones sino que hacen parte de las diversas manifestaciones de un verdadero principio de acuerdo con el cual la determinación de la relación condicionante beneficia y perjudica al tercero que es titular de la relación condicionada. iObsérvese cuán curioso es el hecho de que las posiciones principioexcepción terminen invirtiéndose con tal precisión!”.

${ }^{64}$ Rosende (2001), p. 498.

${ }^{65}$ Señala Allorio (2014), p. 104, crítico de la teoría de los "efectos reflejos de la sentencia", y me adhiero plenamente: "la autoridad de la cosa juzgada frente a terceros es la misma autoridad de la cosa juzgada sobre la relación decidida (cuyos sujetos normalmente será las partes entre las cuales fue decidida). En conclusión, los terceros sufren un perjuicio o un beneficio jurídico como consecuencia de la sentencia, en razón que se trata de una sentencia revestida de cosa juzgada que decide sobre tal relación, es decir, sobre aquella relación jurídica prejudicial (o condicionante) de aquella relación suya que es dependiente”. 
"se trata de un efecto de cosa juzgada que se aleja de los principios generales aceptados en la materia: ante todo, porque el objeto de la acción civil es materialmente diferente de la acción penal" ${ }^{\prime 66}$,

fundándose en que "se ha fallado" de esa forma, y en lo dispuesto en el art. 180. Arturo Alessandri es de la misma opinión ${ }^{67}$.

Alex Carocca, al contrario de Enrique Barros, es crítico de este efecto extensivo, y postula la "necesidad de derogar las excepciones que extienden el efecto de cosa juzgada de la sentencia absolutoria a quienes no han intervenido en el proceso penal", denunciando incluso la "inconstitucionalidad" de los arts. 179 y 180, por la supuesta infracción al debido proceso $^{68}$. Dice, además:

"en el nuevo sistema penal las sentencias absolutorias penales se pronuncian de acuerdo a un estándar probatorio más bajo o, por lo menos, distinto que aquel que se exigía en el antiguo Código de Procedimiento Penal de 1906, concordante a su vez con el sistema de prueba legal o tasada..." ${ }^{\prime}$.

Si bien es cierto que solo para condenar el juez penal requiere una convicción más allá de toda duda razonable, ello en caso alguno significa que las sentencias absolutorias sean fruto de una aplicación arbitraria de la ley, o una deficiente ponderación de hechos; asimismo, la libre valoración probatoria parece a todas luces un sistema de insuperable calidad frente al de la prueba legal o tasada.

No es nueva esta objeción acerca de la eventual injusticia que encierra la sentencia pronunciada sin la comparecencia del tercero, como ya hemos dicho. Es el legislador chileno quien de forma deliberada ha implementado esta solución que se acusa de injusta, dando prevalencia a la estabilidad de los pronunciamientos por sobre los intereses de la víctima perjudicada. De lege ferenda, sería recomendable permitir la comparecencia del tercero, no solo durante el proceso -como hoy lo permite la ley procesal chilena en su libro I- sino una vez pronunciada la sentencia definitiva en el proceso

${ }^{66}$ Barros (2006), p. 968.

${ }^{67}$ Alessandri (1983), p. 39: "si el acusado ha sido condenado en el juicio criminal como responsable del delito o cuasidelito, o ha sido absuelto o se ha decretado el sobreseimiento definitivo en su favor por alguna de las circunstancias taxativamente señaladas en el art. 202 C.P.C. [hoy art. 179], la sentencia dictada en lo criminal produce cosa juzgada en materia civil no sólo respecto de los que hayan sido partes en el proceso criminal, sino de todos, erga omnes".

${ }^{68}$ CARocca (2006), p. 46.

${ }^{69} \mathrm{Ibid}$. 
en que no intervino, con la prerrogativa de oponerse a ella ${ }^{70}$. Robert Alexy ha dicho:
"la seguridad jurídica [en este caso, la estabilidad de la sentencia] es un valor importante pero no el único. El valor de la seguridad tiene que ser sopesado con el de la justicia material",

aludiendo a la "fórmula radbruchiana", que solo relega la seguridad jurídica cuando esta genera soluciones "insoportablemente injustas" un patrón que el juez jamás debiera perder de vista al aplicar el art. 179 a los terceros que no comparecieron al proceso.

El efecto erga omnes de la sentencia absolutoria y del sobreseimiento corresponde, en todo caso, solo a una dimensión del problema. Como podrá el lector advertir, y como quedará claro de los casos que la jurisprudencia ha conocido, existirá casi siempre una influencia decisiva de la ley civil sustantiva referida a la responsabilidad por el hecho ajeno (dependientes, incapaces, etc.) que no se agota en la simple aplicación irrestricta de la sentencia absolutoria o del sobreseimiento anterior respecto del tercero. Será necesario utilizar la pauta comparativa propuesta en este trabajo

${ }^{70}$ Cfr. Nieva (2006), pp. 211-214. El autor reconoce la existencia de una laguna legal a este respecto en la legislación española, idéntico al que existe en la ley procesal chilena, proponiendo una solución similar a la de los arts. 582 a 592 del Código Procesal Civil francés, "que abre la posibilidad a un tercero perjudicado por una resolución judicial, de que solicite la revisión de dicha resolución por el mismo juez que la dictó, teniendo en cuenta que el anterior proceso fue sustanciado sin él. De ese modo, el Juez volverá a juzgar los puntos que le señale el tercero, como si, de hecho, estuviera completando el proceso ya celebrado con los argumentos que le da el tercero. El plazo para intentarlo es, normalmente, de treinta años desde la fecha de la sentencia, y de dos meses si la sentencia le hubiere sido notificada al tercero". Allorio (2014), p. 79, con toda razón dice: "también se ha argumentado, con fórmulas genéricas, que la sentencia no puede agredir la posición autónoma de los terceros, a los cuales corresponde salvaguardar. Para desvirtuar este argumento, debe tenerse en cuenta que la autonomía a la cual se está aludiendo también puede entenderse como una exigencia práctica digna de tutela, con lo cual, aquélla puede constituir una sugerencia a ser tomada en consideración por el legislador para futuras reformas, pero no existe indicio alguno de que se trate de una exigencia materializada en el Derecho codificado. En lugar de autonomía, en el Derecho codificado lo que existe es más bien dependencia (que por lo demás es la otra cara de la prejudicialidad), o en otras palabras, subordinación, y tal subordinación no es de personas, ni tampoco de intereses, sino de relaciones jurídicas". Hay que hacer el alcance que en el Derecho italiano el tercero puede oponerse a una sentencia definitiva y firme emanada de un proceso del que no fue parte y que le perjudica, como consagra el art. 510 de la ley procesal de ese país. Para Liebman (1946), p. 140, se trata simplemente de una facultad del tercero y, por lo tanto, si guarda silencio, la sentencia no le afectaría de acuerdo con el límite general subjetivo de la cosa juzgada. Allorio (2014), p. 283, sostiene la tesis contraria.

${ }^{71}$ Alexy (2014), p. 58, en referencia a Radbruch (2013), pp. 178-179. 
para examinar si existirá incompatibilidad entre la exoneración penal y el contenido de la nueva demanda civil. Así, si en la demanda civil se reclama la culpa del empleador por el hecho ajeno del dependiente y este había sido exonerado previamente en sede penal donde se había perseguido también un delito imprudente, todo indica que la sentencia aprovechará al tercero, salvo que en la demanda se impute una conducta negligente no abarcada por la exoneración penal ya decretada. También, si el dependiente fue sobreseído por haberse estimado que su conducta no fue dolosa, pero nada se dijo sobre su negligencia, no habría problema en someter a un juicio civil posterior al empleador en que se le impute una conducta negligente.

\section{JURISPRUDENCIA ACERCA DEL EFECTO ERGA OMNES \\ DE LA SENTENCIA ABSOLUTORIA Y DEL SOBRESEIMIENTO}

El efecto erga omnes de la cosa juzgada penal en el juicio civil ha sido objeto de interpretaciones judiciales dispares, aunque la abrumadora mayoría de los fallos la reconocen, en especial, cuando se reúnen los siguientes requisitos copulativos:

(a) pronunciamiento acerca de la responsabilidad del tercero civilmente responsable en accidentes de tránsito (empresa propietaria del vehículo o empleador del conductor),

(b) existió un sobreseimiento definitivo o absolución penal que benefició a quien intervino directamente en el accidente, fundado en que no existió delito o cuasidelito y

(c) esa inexistencia está asentada sobre la falta del elemento subjetivo del tipo (dolo o culpa).

En general, las soluciones parecen justas si se entiende que la falta de negligencia del imputado beneficia también al tercero civilmente responsable.

A continuación, revisaré algunos $\operatorname{casos}^{72}$. La sentencia de la Corte Suprema del caso Riveros con Tracción Eléctrica (1913) rechazó la apli-

${ }^{72}$ Como exponía al comienzo de este trabajo, hasta antes de la entrada en vigencia del Código Procesal Penal en todo el territorio chileno, durante la vigencia del antiguo Código de Procedimiento Penal, la víctima gozaba de una facultad muy amplia de interponer demanda civil en el mismo proceso penal, prerrogativa que se empleó en la mayoría de los casos. Sin embargo, existió siempre la discusión de si era procedente -dentro del proceso penal- la demanda civil en contra de terceros civilmente responsables. CORRAL (2004), p. 57, cita un fallo de la Corte de Apelaciones de Santiago que declaró no ha lugar a la demanda civil interpuesta en un proceso penal contra el propietario de un vehículo, tercero civilmente responsable, "porque de no interpretarse así, se extenderían los efectos de la sentencia criminal, en lo que dice relación a las responsabilidades civiles derivadas del cuasidelito, a quien no fue parte en el proceso", aunque acota que después la Corte Suprema anuló 
cación del art. 179 alegada por la empresa de tranvías, sobre la base de la exoneración penal del conductor, porque

"no habiendo sido materia del juicio criminal el juzgamiento y fallo
de la responsabilidad que pudiera resultar de la falta de colocación
del salvavidas reglamentario, la sentencia de sobreseimiento invo-
cada en esta causa para fundar la excepción no reuniría, bajo este
aspecto, las condiciones previstas en el número $1^{\circ}$ del artículo 202 ya
citado [actual art. 179] para producir la cosa juzgada en los civil..."

esa sentencia por la vía del recurso de queja. Como da cuenta la jurisprudencia que se analiza a continuación, la inmensa mayoría de los casos se refieren a acciones en contra de terceros civilmente responsables. Solo en años recientes, ya en vigor la Reforma Procesal Penal, se encuentran sentencias de los tribunales superiores en que es el propio demandado directo quien opone la excepción de cosa juzgada, fundada en su propio sobreseimiento o absolución en un juicio penal anterior.

${ }^{73}$ Un criterio similar se siguió en la sentencia González con Empresa de Ferrocarriles del Estado (1923) en un proceso civil seguido contra esta última, por la muerte de un pasajero. Dijo la Corte de Apelaciones de Santiago: "la sentencia [sobreseimiento fundado en la ocurrencia de un caso fortuito] dictada en el proceso criminal seguido en Curicó sólo tiene fuerza obligatoria en ese proceso criminal, el cual no podrá ser renovado porque la cosa juzgada lo impide; pero no produce fuerza ni efecto alguno en esta causa 46 en que se persigue una responsabilidad civil, por un cuasi-delito civil”. Este fallo entendió erróneamente que el actual art. 179 exige la concurrencia de la triple identidad legal de toda cosa juzgada, la que no existía en ese caso, por no haber sido la empresa demandada parte en el juicio penal. La Corte Suprema confirmó esta resolución, no entrando al fondo del asunto sobre la base de similares argumentos que los esgrimidos en la sentencia de 13 de septiembre de 1923 que se detalla en el siguiente pie de página. La sentencia del caso Saavedra con Compañía de Tracción y Alumbrado Eléctricos de Santiago (1911) también rechazó aplicar la excepción de cosa juzgada alegada por la demandada, en los siguientes términos: “....aun cuando en el auto de sobreseimiento definitivo que puso término a esa investigación y en el cual se funda la excepción de cosa juzgada, se haya declarado casual el hecho pesquisado y debido a imprudencia de la víctima, tal antecedente, si bien puede ser bastante para afirmar la inexistencia de un delito o cuasi-delito imputable al conductor o motorista del tranvía que ocasionó el accidente, no lo es materia alguna para declarar la irresponsabilidad civil de la Empresa demandada, que ha podido ser negligente en el servicio por circunstancias aplicables a ella sola, y cuya actuación en esta materia no pudo ser discutida en el proceso criminal, en el cual ni siquiera fue parte". En términos similares resolvió la Corte Suprema en el caso Urquieta con Tracción Eléctrica (1917), rechazando la excepción de cosa juzgada alegada por la Empresa de Tracción y Alumbrado Público, por las lesiones sufridas por el demandante al atravesar la línea del tranvía, siendo atropellado. Dijo la Corte: “...no se persigue en este pleito la responsabilidad civil de ese empleado ni tampoco la de la Empresa, emanada del delito o del cuasi delito criminal de Antúnez, único caso en que la sentencia que lo absolvió de la acusación por la no existencia del delito o cuasi delito pesquisados [que estableció la imprudencia de la víctima, quien cruzó en estado de ebriedad], produciría cosa juzgada en la demanda civil”. En el mismo sentido, la sentencia de la Corte Suprema del caso Asenjo con Compañía de Tranvías Eléctricos (1921) que rechazó la cosa juzgada alegada por la demandada, resolviendo: "en este juicio 
En este caso, la Corte distinguió claramente que una cosa es la culpa del conductor, que había sido exonerada en sede penal, y otra diferente es la negligencia de la propia empresa, no aprovechando la primera al segundo.

Sin embargo, poco tiempo después, la Corte Suprema pareció cambiar de forma drástica de criterio en un caso muy similar. La sentencia del caso Cerda con Compañía de Tranvías Eléctricos de Valparaíso (1919), resolvió aplicar el art. 179 porque

"la principal [razón] ha sido la de evitar que sobre un mismo hecho se produzcan dos resoluciones judiciales contradictorias, como podría suceder en el presente caso si se rechazara la excepción de cosa juzgada y seguido el juicio civil se declarase la responsabilidad de la Empresa demandada, puesto que esta responsabilidad sólo podrá basarse en la culpabilidad de uno de los empleados de dicha Empresa, siendo así que ya otra resolución judicial, la del juicio criminal, había declarado lo contrario, o sea, que el accidente se había debido exclusivamente a la imprudencia de la víctima y que no se podía culpar a nadie de la desgracia",

aduciendo también que el art. 179 no requiere que exista triple identidad legal entre los dos procesos.

En el caso Aroseau con Ferrocarriles del Estado (1923), se acogió por la Corte de Apelaciones de Valparaíso la excepción de cosa juzgada opuesta por una empresa de ferrocarriles, respecto de su responsabilidad civil por un accidente que causó la muerte de una persona que esperaba en el andén (demandó su viuda). Resolvió la Corte:

"que resuelto por la justicia criminal que no hubo delito ni cuasidelito en el accidente que produjo la muerte del señor Noel y que ésta se debió a su propia imprudencia, sobreseyéndose definitivamente al respecto, la cosa juzgada que se deriva de ese fallo, debe aprovechar el tercero civilmente responsable, o sea, en este caso a la Empresa de los Ferrocarriles del Estado, que ha sido demandada por actos de sus dependientes" ${ }^{\prime 4}$.

Asenjo se ha limitado a la indicada Empresa de Tranvías por daños de origen meramente civil (...) elementos del todo ajenos a la jurisdicción criminal y constitutivos únicamente de una acción civil ordinaria...”. En el mismo sentido, la sentencia del caso Almarza con Ferrocarriles del Estado (1939) de la Corte Suprema.

${ }^{74}$ Agregó la Corte: "en efecto, si lo declarado por el tribunal criminal, es una verdad que no puede ser discutida por nadie, no se divisa razón para hacerse una excepción en contra del civilmente responsable por los actos de un tercero; y si la responsabilidad por el hecho ajeno tiene como fundamento necesario la ilicitud del acto ejecutado por la 
Los restantes fallos de la Corte Suprema, citados por el Repertorio de Legislación y Jurisprudencia, han reconocido el efecto erga omnes a favor del tercero civilmente responsable, respecto del sobreseimiento definitivo o absolución penal por inexistencia del delito o cuasidelito ${ }^{75}$.

persona por quien se responde, y si es una verdad declarada que no hubo hecho ilícito, y si no puede perseguirse ni aun al directamente responsable, porque obra en su favor la cosa juzgada, no es aceptable que pueda perseguirse la responsabilidad del tercero, obligado sólo indirectamente". La Corte Suprema rechazó el recurso de casación en el fondo interpuesto por la demandante en contra de esta sentencia, sin entrar al fondo del asunto, aduciendo que aun cuando existiera la infracción al actual art. 179, ello no influiría de forma alguna en lo dispositivo del fallo, ya que no tiene la Corte Suprema competencia para alterar los hechos ya asentados en la causa, uno de los cuales sería la inexistencia del delito o cuasidelito penal declarado en sede penal.

${ }^{75}$ En el mismo sentido, sentencia del caso Gómez con Compañía de Catres La Central (1932): "se ha consignado que, según el proceso criminal, el hecho que motivó el accidente que produjo la lesión del recurrente fue casual, y por lo tanto, no constitutivo de delito de parte del empleado de la empresa demandada, y que por ese motivo se mandó sobreseer definitivamente la causa (...) es indudable que acogerse la excepción de cosa juzgada se ha aplicado correctamente la ley". También la sentencia Schulze con Compañía de Ascensores de Valparaíso (1936): "la resolución que se pronuncia en la forma expresada [sobreseimiento penal] acarrea cosa juzgada en lo civil, toda vez que, de no ser así, se correría el riesgo de que, acerca de un mismo asunto y en vista de idénticas circunstancias, se dictaran, por diversos funcionarios del orden judicial, que estuvieren en franca pugna, lo que socavaría el prestigio de que aquellos necesitan estar revestidos para el desempeño de su cargo". En la sentencia del caso García con Empresa de Ferrocarriles del Estado (1958) se acogió también la excepción de cosa juzgada en los siguientes términos: "que la cosa juzgada es una institución jurídica que tiene por objeto impedir que en un nuevo proceso se pretenda juzgar lo mismo que ya se juzgó en otro anterior, evitando así que se produzcan nuevas pruebas que desvirtúen lo que se dio por probado o por improbado en un proceso o que se discuta o se interprete nuevamente el alcance de las disposiciones legales en relación con un hecho o con un contrato entre las mismas partes que lo fueron en un juicio anterior. En la especie, en el proceso criminal, como ya se ha dicho, se investigó todo lo relacionado con las causas mediatas o inmediatas que causaron o pudieron causar el accidente y el proceso terminó declarando expresamente que éste fue el resultado de un caso fortuito". En la sentencia de la Corte Suprema del caso Rubilar con Ferrocarriles del Estado (1962) también se exoneró de responsabilidad civil a la demandada en similares términos: "que como se advierte, la sentencia absolutoria o el sobreseimiento en el caso en examen, se funda en la inexistencia de todo dolo o culpa por parte del procesado y sin uno u otro, no puede haber delito ni cuasidelito civil ni penal, pues no hubo responsabilidad de parte del procesado y es indiscutible que la responsabilidad del demandado civil resulta de la participación dolosa o culpable del procesado penal establecida en forma irrefragable como una consecuencia necesaria de la calidad de autor, presupuesto son el cual esta acción es inocurrente (sic)". En el mismo sentido se acogió la excepción de cosa juzgada en las sentencias de los casos Cruz y otros con Compañía de Cervecerías Unidas (1921) de la CA de Valparaíso; de la Corte Suprema en el caso Vega con Chilean Electric Tranway (1925); Mardones con Compañía Chilena de Electricidad (1930), sobre la base de la existencia de un sobreseimiento definitivo penal que declaró que un accidente de tranvía con resultado de muerte había sido casual. Igual cosa sucedió en la sentencia del 
Hay que acotar que en estos casos la inexistencia del delito o cuasidelito que sirvió de fundamento a la absolución o sobreseimiento definitivo, sustenta, a su vez, la exoneración de responsabilidad civil, dando forma a la idea de "dependencia", "subordinación" y "requisito lógico", propio de la prejudicialidad de esta cosa juzgada. En general, no hay mayor análisis material acerca de la posible coincidencia en cuanto a los hechos, o si la inexistencia de culpa (que es la razón principal de la irresponsabilidad penal) es extrapolable al estatuto civil, o sea, que la falta de culpa penal equivale a la inexistencia de culpa civil ${ }^{16}$.

Un fallo reciente de la Cuarta Sala de la Corte Suprema, del caso Catalán con Sandoval (2011) sigue el criterio de los últimos fallos citados, confirmando el de la Corte de Apelaciones de Antofagasta, que había resuelto la apelación de la misma causa. En ese caso la demanda se interpuso contra el dueño de un vehículo motorizado, tercero civilmente responsable respecto de los daños ocasionados por el conductor. Estos hechos ya habían sido investigados y sobreseídos en forma definitiva en sede penal, por no ser constitutivo de delito. Nuestro Máximo Tribunal razonó:

"en el caso en estudio, el sobreseimiento definitivo se decretó fundado en la causal contemplada en la letra a) del artículo 250 del Código Procesal Penal, esto es, cuando el hecho investigado no es constitutivo de delito, porque la víctima se situó en un lugar donde no debía, exponiéndose en forma imprudente, por lo que no hubo negligencia de parte del conductor microbús, en contra de quien se dirige la acción",

y que

"en consecuencia, si la sentencia absolutoria dictada en el proceso penal se fundó en la inexistencia del hecho ilícito imputado al

caso Cabello con Compañía Chilena de Electricidad de Valparaíso (1936) pronunciada por la Corte Suprema, que acogió la cosa juzgada alegada por la demandada civil Compañía de Electricidad de Valparaíso, respecto de la muerte de un pasajero.

${ }^{76}$ Tampoco hay mayor análisis en estos fallos respecto de la naturaleza y alcance de la responsabilidad del empleador respecto de los ilícitos perpetrados por sus empleados. El sistema chileno, como acota CORRAL (2004), p. 231, "parece haber seguido una mezcla entre el sistema de la responsabilidad vicaria y el sistema de la responsabilidad por culpa", o sea, el factor de imputación para el empleador en estos casos sería, no solo la negligencia del empleado (sobreseída en sede penal) sino, también, la negligencia del empleador en no haber adoptado sus propias medidas que evitaran el accidente, culpa in eligiendo y culpa in vigilando, etc. Por tanto, en estos casos podría suceder que sea razonable exonerar de responsabilidad civil al empleador, si la responsabilidad penal análoga del empleado ya fue desestimada; no así si es posible estimar que existen otras faltas de diligencia del empleador que no se identifican con la negligencia desplegada por el subalterno. 
chofer del microbús- como lo decidieron los jueces del fondoconcurrían los presupuestos legales para acoger la excepción de cosa juzgada y rechazar la demanda”.

En consecuencia, "el efecto de cosa juzgada en este caso es de carácter universal". La Corte de Apelaciones de Santiago ha seguido también un criterio similar en sus fallos recientes, como el del caso Martínez con Transportes Elecing (2011), la que no fue revisada por la E. Corte Suprema, también referida a la responsabilidad civil del propietario de un vehículo motorizado por las lesiones ocasionadas por un accidente. Esa Corte decidió acoger la excepción de cosa juzgada civil en razón de

"la no existencia del delito o cuasidelito que ha sido materia del proceso, que es precisamente lo acontecido en la causa criminal rol 4148-2002”.

La misma Corte de Apelaciones de Santiago también absolvió de toda responsabilidad civil en el caso de un empleador por la muerte de un trabajador. El fallo del caso Sandoval con Ingeniería y Construcción Sigdo Koppers S.A. $(2010)^{77}$, da cuenta de la demanda civil interpuesta contra la empresa Sigdo Koppers S.A. por la muerte de un empleado, estableciéndose:

“en la causa criminal antes referida se absolvió de toda responsabilidad a los dependientes de la empresa (...), quienes fueron procesados y acusados por cuasidelito de homicidio y lesiones, sentencia que no fue impugnada, quedando ejecutoriada".

Acotó a continuación este fallo:

“de conformidad con el numeral $1^{\circ}$ del artículo 179 del Código de Procedimiento Civil, que señala que las sentencias que absuelvan de la acusación o que ordenen el sobreseimiento definitivo sólo producirán cosa juzgada en materia civil cuando se funden en la no existencia del delito o cuasidelito que ha sido materia del proceso, cuyo es el caso, según se advierte de la lectura de la sentencia”.

${ }^{77}$ Esta sentencia no fue revisada por la Corte Suprema, sin perjuicio que ante ese tribunal (causa 9317-2010) las partes finalmente conciliaron con fecha 30 de agosto de 2012 , acto procesal que en nada afectó el contenido de la sentencia emanada de la Corte de Apelaciones de Santiago. 


\section{Sin embargo, hay que señalar que este criterio no ha sido uniforme en nuestros tribunales superiores ${ }^{78}$.}

${ }^{78}$ En la causa Carrizo con Vilela (2012) seguida ante la Corte de Apelaciones de Antofagasta, se persiguió la responsabilidad civil del conductor de un bus y de su propietaria inscrita, por la muerte ocasionada a una menor de edad en un accidente de tránsito. A pesar haberse absuelto penalmente al conductor, en un juicio criminal ante el Juzgado de Garantía de esa ciudad (la sentencia no dice por qué motivo fue absuelto), la Corte desestimó que en el caso resultara aplicable la excepción de cosa juzgada alegada por las demandadas, sin dar mayores razones, más que reafirmar su autonomía para resolver acerca de la responsabilidad civil. Aunque el caso llegó a la Corte Suprema por la vía de la casación (rol 546-2013), el recurso nunca fue fallado, por haber llegado las partes a un avenimiento el 18 de julio de 2013.

También, en un fallo muy reciente de la Cuarta Sala de la Corte Suprema, caso Bustamante con Amenábar (2012) se rechazó la casación en el fondo interpuesta por el conductor de un vehículo, Hernán Amenábar Correa, y el propietario inscrito, Viña Undurraga S.A., ambas demandadas civiles por las lesiones ocasionadas a un tercero en un accidente de tránsito. La sentencia de primera instancia, como la de segunda, confirmaron la condena civil, denunciando los demandados la infracción, entre otras normas, del art. 179.1, fundado en que ya habían existido dos procesos penales, uno de ellos que solo había condenado al demandado Amenábar por el delito de conducción en estado de ebriedad, pero que había sobreseído la causa en lo referido al delito imprudente de lesiones. Así también, invocaron que existió otro proceso penal, en contra de la codemandada Miriam Proschle, que la había condenado como autora del delito imprudente de lesiones. La Corte rechazó que hubiere infracción al art. 179, señalando: "la sentencia que condenó al demandado Amenábar como autor del delito de conducir vehículo motorizado en estado de ebriedad, no ha podido producir efecto de cosa juzgada en este juicio civil en la medida en que en dicho fallo condenatorio no se resolvió expresamente sobre la relación de causalidad habida entre la inconducta del condenado Amenábar allí investigada y sancionada y las lesiones causadas a la demandante Bustamante. Asimismo, como dicho proceso no se ha tenido a la vista, no puede darse por establecido que se tuvieron por probados hechos que se vinculan con esta causa y que hayan servido de necesario fundamento al fallo condenatorio. En otros términos, en el presente juicio civil la responsabilidad perseguida respecto del demandado Amenábar se basa en calificaciones jurídicas distintas a las de la sentencia penal dictada en el proceso seguido en su contra por conducir en estado de ebriedad, lo que conduce a descartar el pretendido efecto de cosa juzgada" y "que, por otra parte, en materia de sentencias penales absolutorias la regla general está constituida por el hecho que ellas no producen efecto en materia civil, según se desprende del artículo 179 del Código de Procedimiento Civil, salvo que se presenten las situaciones específicamente previstas en esa norma. De la presentación en examen se deduce que la sentencia absolutoria que se hace valer por los recurrentes estaría constituida por la dictada en el cuasidelito de lesiones. Sin embargo, ese fallo condena a la otra demandada de este juicio y nada resuelve acerca del demandado Amenábar. Ninguna de las situaciones previstas en el citado artículo 179 se presentan en la especie en relación con el referido demandado Amenábar; simplemente no hay pronunciamiento al respecto, ni siquiera se dictó sobreseimiento en su favor. En consecuencia, el reclamado efecto de cosa juzgada atribuido a una supuesta sentencia absolutoria penal debe ser excluido”. 


\section{Conclusiones}

1. La norma del art. $179.1^{\circ}$ del Código de Procedimiento Civil consagra una cosa juzgada sui generis que no exige la concurrencia estricta de la triple identidad legal entre personas, cosa pedida y causa de pedir, esto es, que no reconoce límites objetivos ni subjetivos. Sin perjuicio de ello, entre la absolución o sobreseimiento penal y el proceso civil en que se hará valer esta cosa juzgada, debe existir una coincidencia en los hechos ventilados, de forma tal que no se generen sentencias contradictorias y que la sentencia anterior finalmente termine invalidada por el nuevo fallo. Esta coincidencia muchas veces significará una efectiva identidad de partes, y a la luz de la doctrina y jurisprudencia, una identidad en el reproche buscado por la pena y el reproche implícito en la condena pecuniaria civil.

2. Buena parte de la doctrina nacional se inclina por acotar el alcance de esta norma, solo a los casos en que la sentencia penal o el sobreseimiento definitivo resolvieron que el hecho no existía, apartándose del tenor literal y de la interpretación respetuosa de los derechos del imputado, que es hacer extensivo este efecto respecto de aquellos casos en que el juicio penal concluyó porque el delito $o$ cuasidelito no existieron. Para resolver ese error, se hace necesario efectuar un análisis comparativo de las categorías dogmáticas de la responsabilidad civil y penal, poniendo énfasis en los aspectos menos comprendidos, como son: el dolo, la culpa, las causales eximentes y de inimputabilidad penal y civil.

3. Una vez corroborado que existe una amplia coincidencia, es necesario ahondar en la razón material específica de esta cosa juzgada respecto del personalmente absuelto o sobreseído: el derecho fundamental garantizado del imputado del non bis in idem consiste en no ser enjuiciado civilmente una vez que ha sido absuelto en sede penal. Este derecho prevalece frente al interés de la víctima de ver resarcidos los perjuicios ocasionados por el delito o cuasidelito, cuando existen coincidencias relevantes entre el caso penal y civil.

4. Más allá de las teorías acerca del efecto reflejo de la sentencia o de la cosa juzgada, o de su prejudicialidad, la doctrina y la jurisprudencia parecen estar contestes en que la sentencia absolutoria o el sobreseimiento definitivo produce efecto de cosa juzgada erga omnes, constituyendo una clara excepción a los límites subjetivos de la cosa juzgada, y estableciendo una clara preferencia aun por sobre de los intereses de la víctima civil, en aras de la estabilidad de los procesos, sobre todo en aquellos casos en que se beneficia 
al tercero civilmente responsable. Lo anterior, sin perjuicio de la aplicación de la ley civil de fondo referida a la responsabilidad por el hecho ajeno.

\section{Bibliografía CITADA}

AlCALDE, Enrique (2011). "Aplicación de los principios de tipicidad, culpabilidad y proporcionalidad en la investigación administrativa". Revista Actualidad Jurídica. Santiago. julio.

AlCALDE, Enrique (2013). La responsabilidad de los directores de sociedades anónimas,. Santiago: Ediciones Universidad Católica de Chile.

Alessandri, Arturo (1983). De la responsabilidad extra-contractual en el derecho civil chileno. Santiago: Editorial Jurídica Ediar/Conosur Ltda.

Alessandri, Arturo, Manuel Somarriva y Antonio Vodanovic (1998). Tratado de Derecho Civil. Partes preliminar y general. Santiago: Editorial Jurídica de Chile. tomo I.

Alexy, Robert (2012). Teoría de la argumentación jurídica. Madrid: Centro de Estudios Políticos y Constitucionales.

AleXy, Robert (2014). El concepto y la validez del derecho. España: Editorial Gedisa.

Allorio, Enrico (2014). La cosa juzgada frente a terceros. Madrid: Editorial Marcial Pons.

ArnaIz, Amaya (2004). La acción civil en el proceso penal. Tesis doctoral. Madrid: Biblioteca Universidad Carlos III.

Baquerizo, Jorge (2009). "Colisión de Derechos Fundamentales y Juicio de Ponderación”. Revista Jurídica de la Facultad de Derecho de la Universidad Católica de Guayaquil, tomo 1. 2009, disponible en www.revistajuridicaonline.com

Barros, Enrique (2006). Tratado de Responsabilidad Extracontractual. Santiago: Editorial Jurídica de Chile.

Bordalí, Andrés (2011). "La acción penal y la víctima en el Derecho chileno". Revista de Derecho de la Pontificia Universidad Católica de Valparaíso. $\mathrm{N}^{\circ} \mathrm{xxxvII.}$ Valparaíso.

CARocca, Alex (2006). "Algunas consideraciones sobre los efectos de las sentencias penales absolutorias en los procesos civiles". Revista Procesal Penal. $\mathrm{N}^{\mathrm{O}}$ 54. Santiago. Editorial LexisNexis.

Casarino, Mario (1983). Manual de Derecho Procesal. Santiago: Editorial Jurídica de Chile. Tomo III.

Corral, Hernán (2004). Lecciones de Responsabilidad Civil Extracontractual. Santiago: Editorial Jurídica de Chile.

Cury, Enrique (2009). Derecho Penal Parte General. Santiago: Ediciones Universidad Católica de Chile. 
Díez Picazo, Luis y Antonio Gullón (1995). Instituciones de Derecho Civil. Madrid: Editorial Tecnos S.A. Tomo I.

Dworkin, Ronald (2012). Los derechos en serio. Barcelona: Editorial Ariel Derecho. ERIKSSON, Lars (1997). "Tendencias conflictivas en el derecho moderno", en Aulis AARNio y otros (compiladores). La normatividad del derecho. Barcelona: Editorial Gedisa.

Ferrajoli, Luigi (2009). Derecho y Razón. Madrid: Editorial Trotta.

Gesualdi, Dora Mariana (1997). Responsabilidad por daños en el tercer milenio. De la antijuridicidad a las causas de justificación. Madrid: Editorial Abeledo-Perrot.

Horvitz, María Inés (2004). Derecho Procesal Penal chileno. Saniago: Editorial Jurídica de Chile.

LeCaros, Raúl (1997). El acto jurídico en el Código Civil chileno. Santiago: Ediciones Universidad Católica de Chile.

Liebman, Enrico (1946). Eficacia y autoridad de la sentencia y otros estudios sobre la cosa juzgada (con adiciones relativas al Derecho brasileño). Buenos Aires: Editorial Ediar S.A.

Mañalich, Juan Pablo (2013). "El estado de necesidad exculpante. Una propuesta de interpretación”, en Enrique Cury Urzúa, Alex van Weezel, Humanizar y renovar el Derecho Penal. Estudios en memoria de Enrique Cury. Santiago: Editorial Thomson Reuters.

MaRín, Juan Carlos (2005). "La acción civil en el nuevo Código Procesal Penal chileno: su tratamiento procesal". Revista de Estudios de la Justicia. $\mathrm{N}^{\circ}$ 6. Santiago.

Mir, Santiago (2012). Tratado de Derecho Penal Parte General, 9ª ed. Barcelona: Editorial Reppertor.

NÁQuira, Jaime (2008). "Principios y penas en el Derecho penal chileno". Revista Electrónica de Ciencia Penal y Criminología. No 10, 2008. Disponible en http:// criminet.ugr.es/recpc/

Nieva, Jordi (2006), La cosa juzgada. Barcelona: Editorial Atelier Libros Jurídicos.

Nieva, Jordi (2010). La cosa juzgada. El fin de un mito. Santiago: Editorial Abeledo Perrot LegalPublishing.

Nieva, Jordi (2014). Derecho Procesal I. Introducción. Barcelona: Editorial Marcial Pons.

NúÑEz, Juan Cristóbal (2003). Tratado del Proceso Penal y del juicio oral. Introducción al estudio del Proceso Penal. Santiago: Editorial Jurídica de Chile.

PizArro, Carlos (2005). "Mirada de un civilista a la reparación en el nuevo proceso penal”. Gaceta Jurídica. N 296. Santiago.

Prieto, Luis (2003). Justicia Constitucional y Derechos Fundamentales. Madrid: Editorial Trotta.

Prieto, Luis (2013). El constitucionalismo de los derechos. Ensayos de filosofía jurídica. Madrid: Editorial Trotta.

Proyecto de Nuevo Código Procesal Civil, disponible en el sitio web del Ministerio de Justicia de Chile: http://rpc.minjusticia.gob.cl 
Puig, José (1997). Fundamentos de Derecho Civil. Barcelona: Bosch Casa Editorial S.A.

Radbruch, Gustav (2013). Introducción a la Filosofía del Derecho. México: Fondo de Cultura Económica.

Repertorio de Legislación y Jurisprudencia, Código de Procedimiento Civil (1983). Santiago: Editorial Jurídica de Chile.

Rodríguez, Pablo (2004). Responsabilidad Extracontractual. Santiago: Editorial Jurídica de Chile.

Romero, Alejandro (2011). La cosa juzgada en el proceso civil chileno. Doctrina y jurisprudencia. Santiago: Editorial Jurídica de Chile.

Romero, Alejandro (2012). "La sentencia judicial como medio de prueba". Revista chilena de Derecho, vol. 39, No 2, Santiago.

Romero, Alejandro (2014). "La reforma Procesal Civil y los trasplantes jurídicos". Actualidad Jurídica. $\mathrm{N}^{\circ}$ 29. Santiago, enero.

Rosende, Cecilia (2001). "Efectos directos y reflejos de la sentencia". Revista Chilena de Derecho, vol. 28, No 3. Santiago.

Roxin, Claus (2008) Derecho Penal Parte General, ciudad: Editorial Thomson Civitas.

Silva, Jesús-María (2001). “¿Ex delicto? Aspectos de la llamada "responsabilidad civil" en el proceso penal”. Indret. $\mathrm{N}^{\mathrm{o}} 3$. julio 2001. Disponible en www. indret.com.

TAPIA, Isabel (2010). La cosa juzgada (Estudio de jurisprudencia civil). Madrid: Editorial Dykinson.

VAN WeEzel, Alex (2013). "Neuroderecho y finalismo jurídico-penal. Consecuencias de los avances", en Enrique Cury Urzúa, Alex van Weezel, Humanizar y renovar el Derecho Penal. Estudios en memoria de Enrique Cury. Santiago: Editorial Thomson Reuters.

Wach, Adolf (1997). Manual de Derecho Procesal Civil. Buenos Aires: Ediciones Jurídicas Europa-América-

\section{Jurisprudencia citada}

\section{Jurisprudencia chilena}

Saavedra con Compañía de Tracción y Alumbrado Eléctrico de Santiago (1911): Corte Suprema, 31 de octubre de 1911 (casación en la forma). Revista de Derecho y Jurisprudencia, t. 4 , sec. $1^{\text {a }}$, p. 139.

Riveros con Tracción Eléctrica (1913): Corte Suprema, 22 de julio de 1913 (casación en la forma). Revista de Derecho y Jurisprudencia, t. 13, sec. $1^{\mathrm{a}}$, p. 300.

Urquieta con Tracción Eléctrica (1917): Corte Suprema, 29 de agosto de 1917 (casación en el fondo). Revista de Derecho y Jurisprudencia, t. 15, sec. 1 ${ }^{\text {a }}$, p. 131.

Cerda con Compañía de Tranvías Eléctricos de Valparaíso (1919): Corte Suprema, 2 de mayo de 1919 (casación en el fondo). Revista de Derecho y Jurisprudencia, t. 17 , sec. $1^{\text {a }}$, p. 103. 
Asenjo con Compañía de Tranvías Eléctricos (1921): Corte Suprema, 16 de septiembre de 1921 (casación en el fondo). Revista de Derecho y Jurisprudencia, t. 21, sec. $1^{\mathrm{a}}$, p. 119.

Cruz y otros con Compañía de Cervecerías Unidas (1921): Corte de Apelaciones de Valparaíso, 1 de septiembre de 1921 (apelación). Gaceta de los Tribunales de $1921, \mathrm{~N}^{\circ} 194$, p. 798.

Aroseau con Ferrocarriles del Estado (1923): Corte Suprema, 12 de septiembre de 1923 (casación en el fondo). Revista de Derecho y Jurisprudencia, t. 22, sec. $1^{\text {a }}$, p. 432.

González con Empresa de Ferrocarriles del Estado (1923): Corte Suprema, 22 de septiembre de 1923 (casación en el fondo). Revista de Derecho y Jurisprudencia, t. 22 , sec. $1^{\mathrm{a}}$, p. 494.

Vega con Chilean Electric Tranway (1925): Corte Suprema, 30 de julio de 1925 (casación en la forma). Revista de Derecho y Jurisprudencia, t. 23, sec. $1^{\circ}$, p. 396.

Mardones con Compañía Chilena de Electricidad (1930): Corte Suprema, 8 de abril de 1930 (casación en el fondo). Revista de Derecho y Jurisprudencia, t. 27, sec. $1^{\mathrm{a}}$, p. 804 .

Gómez con Compañía de Catres La Central (1932): Corte Suprema, 17 de marzo de 1932 (casación en el fondo). Revista de Derecho y Jurisprudencia, t. 29, sec. $1^{\mathrm{a}}$, p. 340 .

Cabello con Compañía Chilena de Electricidad de Valparaíso (1936): Corte Suprema, 22 de julio de 1936 (casación en la forma). Revista de Derecho y Jurisprudencia, t. 33 , sec. $1^{\circ}$, p. 398.

Schulze con Compañía de Ascensores de Valparaíso (1936): Corte Suprema, 23 de noviembre de 1936 (casación en la forma). Revista de Derecho y Jurisprudencia, t. 34 , sec. $1^{\mathrm{a}}$, p. 62 .

Almarza con Ferrocarriles del Estado (1939): Corte Suprema, 13 de enero de 1939 (casación en la forma y en el fondo), Revista de Derecho y Jurisprudencia, t. 36 , sec. $1^{\mathrm{a}}$, p. 478.

García con Empresa de Ferrocarriles del Estado (1958): Corte de Apelaciones de Santiago, 8 de agosto de 1958 (casación en la forma). Revista de Derecho y Jurisprudencia, t. 55 , sec. $1^{\text {a }}$, p. 84.

Rubilar con Ferrocarriles del Estado (1962): Corte Suprema, 23 de mayo de 1962 (casación en el fondo). Revista de Derecho y Jurisprudencia, t. 59, sec. $4^{\mathrm{a}}$, p. 66.

Brañes con Foncea (2007): Corte Suprema, rol 4194-2005, de 13 de agosto de 2007 (casación en el fondo).

Meneses con Tribunal de Garantía de San Fernando (2008): Tribunal Constitucional, rol 815-2007-INA, de 19 de agosto de 2008 (inaplicabilidad).

Chico con Paya y otros (2010): Corte de Apelaciones de Santiago, rol 951-2010, de 27 de diciembre de 2010 (apelación).

Sandoval con Ingeniería y Construcción Sigdo Koppers (2010): Cortes de Apelaciones de Santiago, rol 688-2007, de 18 de agosto de 2010 (apelación). 
Visionone Chile S. A. con Cuarto Juzgado de Garantía de Santiago (2010): Tribunal Constitucional, rol 1404-2009-INA, de 18 de mayo de 2010 (inaplicabilidad).

Catalán con Sandoval (2011): Corte Suprema, rol 3351-2009, de 11 de agosto de 2011 (casación en el fondo).

Martínez con Transportes Elecing (2011): Corte de Apelaciones de Santiago, rol 2964-2010, de 25 de abril de 2011 (apelación).

Bustamante con Amenábar (2012): Corte Suprema, rol 1004-2010, de 21 de agosto de 2012 (casación en la forma y en el fondo).

Carrizo con Vilela y otros (2012): Corte de Apelaciones de Antofagasta, rol 5002012, de 7 de noviembre de 2012 (apelación).

Jurisprudencia española

Montesinos con Sala Penal del Tribunal Militar Territorial Cuarto (1993): STC 37/1993, de 11 de marzo de 1993.

Escudero con Sección Segunda de la Audiencia Provincial de Murcia (1994):

Tribunal Constitucional, STC 40/1994, de 15 de febrero de 1994.

\section{Normas citadas}

Constitución Política de la República.

Código Civil

Código Penal

Código Orgánico de Tribunales

Código de Procedimiento Civil

Código Procesal Penal

Código de Procedimiento Penal.

Ley $\mathrm{N}^{\circ} 18.834$ que aprueba el Estatuto Administrativo. Diario Oficial, 23 de septiembre de 1989 . 